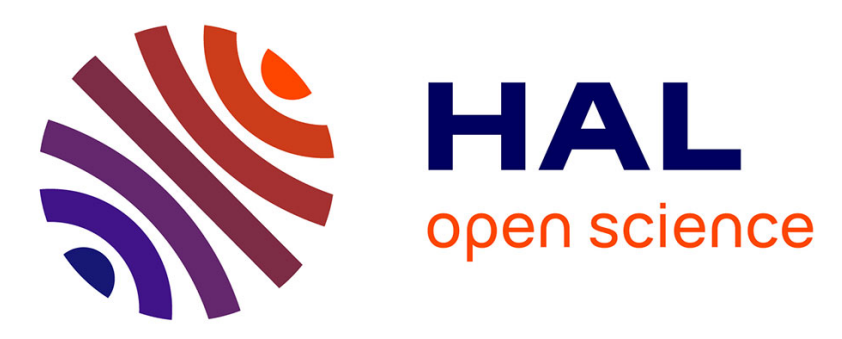

\title{
Pharmacological treatment of schizophrenia with comorbid substance use disorder
}

\author{
Jean-Michel Azorin, Nicolas Simon, Marc Adida, Raoul Belzeaux
}

\section{To cite this version:}

Jean-Michel Azorin, Nicolas Simon, Marc Adida, Raoul Belzeaux. Pharmacological treatment of schizophrenia with comorbid substance use disorder. Expert Opinion on Pharmacotherapy, 2015, 17

(2), pp.231 - 253. 10.1517/14656566.2016.1114101 . inserm-03353004

\section{HAL Id: inserm-03353004 https://www.hal.inserm.fr/inserm-03353004}

Submitted on 23 Sep 2021

HAL is a multi-disciplinary open access archive for the deposit and dissemination of scientific research documents, whether they are published or not. The documents may come from teaching and research institutions in France or abroad, or from public or private research centers.
L'archive ouverte pluridisciplinaire HAL, est destinée au dépôt et à la diffusion de documents scientifiques de niveau recherche, publiés ou non, émanant des établissements d'enseignement et de recherche français ou étrangers, des laboratoires publics ou privés. 


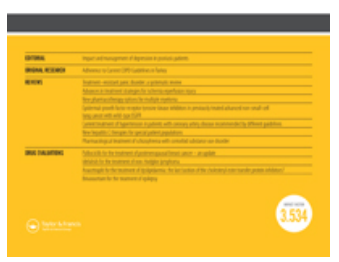

ISSN: 1465-6566 (Print) 1744-7666 (Online) Journal homepage: https://www.tandfonline.com/loi/ieop20

\title{
Pharmacological treatment of schizophrenia with comorbid substance use disorder
}

\author{
Jean-Michel Azorin, Nicolas Simon, Marc Adida \& Raoul Belzeaux
}

To cite this article: Jean-Michel Azorin, Nicolas Simon, Marc Adida \& Raoul Belzeaux (2016) Pharmacological treatment of schizophrenia with comorbid substance use disorder, Expert Opinion on Pharmacotherapy, 17:2, 231-253, DOI: 10.1517/14656566.2016.1114101

To link to this article: https://doi.org/10.1517/14656566.2016.1114101

册 Published online: 04 Dec 2015.

Submit your article to this journal $\sqsubset$

Џll Article views: 710

Q View related articles $₫$

View Crossmark data \lceil

4 Citing articles: 4 View citing articles 


\title{
Pharmacological treatment of schizophrenia with comorbid substance use disorder
}

\author{
Jean-Michel Azorin ${ }^{\mathrm{a}}$, Nicolas Simon ${ }^{\mathrm{b}}$, Marc Adida ${ }^{\mathrm{a}}$ and Raoul Belzeaux ${ }^{\mathrm{a}}$ \\ aDepartment of Psychiatry and Addiction Medicine, South Hospitals, Marseille, France; ${ }^{b}$ Aix-Marseille University, INSERM, UMR912 (SESSTIM), \\ Marseille, France
}

\begin{abstract}
Introduction: While antipsychotics remain the cornerstone of treatment for schizophrenic patients with comorbid substance use disorder (SUD), such treatment is nonetheless complicated by frequent medical comorbidity and poor adherence to medication. Areas covered: Randomised controlled trials (RCTs) on the efficacy of antipsychotics for the treatment of schizophrenic patients with comorbid SUD are reviewed and analysed on the basis of a systematic literature search (PubMed) ranging from 1985 to 2015. On the same basis, findings from RCTs on the efficacy of psychotropic and other medications used for primary SUD are summarised, and the main issues liable to influence treatment choice are discussed, including pharmacodynamic as well as pharmacokinetic interactions, adherence, medical comorbidity and the impact on brain structure. Expert opinion: As far as the treatment of schizophrenic patients with SUD is concerned, direct and indirect evidence tends to stand in favour of the use of second-generation antipsychotics (SGAs), and particularly those with lower metabolic, cardiovascular and extrapyramidal side effects, as well as those with a depot formulation. A few of the usual medications for the treatment of primary SUD, such as naltrexone and disulfiram for alcohol use and bupropion for tobacco cessation, can also be safely and efficiently administered to schizophrenic patients with SUD.
\end{abstract}

ARTICLE HISTORY

Received 15 June 2015

Accepted 26 October 2015

\section{KEYWORDS}

Antipsychotics; co-occurring disorder; pharmacotherapy; schizophrenia; substance use disorder

\section{Introduction}

The high prevalence of comorbid substance use disorder (SUD) among schizophrenic patients seems to increase over time.[1-3] In the US, rates of comorbidity were found to vary between $47 \%$ and $70 \%,[4-6]$ being almost three times more prevalent than in the general population.[6] The most frequent substances used by schizophrenic patients are nicotine (32-92\%),[7] alcohol (20$60 \%),[8]$ cannabis $(12-42 \%),[8]$ cocaine (15-50\%) [8] and amphetamines (10-25\%).[9] Furthermore, many schizophrenic patients use more than one substance.[10]

SUDs exert a negative impact on the course of schizophrenia. Comorbid patients are younger at the onset of symptoms and display higher relapse rates, more frequent and longer hospitalisations, more violent episodes and higher suicidality. They also have an elevated risk of extrapyramidal symptoms (EPSs) and comorbid medical conditions, together with a higher rate of unemployment, as well as poor adherence to treatment.[10-17] Several factors have been associated with SUD among schizophrenic patients, such as the male gender, a lower level of education, a recent experience of homelessness, childhood behavioural problems or a history of major depression.[18] Different hypotheses have been suggested to account for the aetiology of SUD among schizophrenic patients. If we consider self-medication as a likely theoretical hypothesis, patients may be using substances to alleviate their symptoms or the side effects of antipsychotic medication.[19] The affect regulation model hypothesis, which is close to the former, suggests that individuals who use substances to cope with their disorder may share traits of negative affects and disinhibition, which predispose them to maladaptive coping.[20] Another hypothesis suggests a brain reward circuitry dysfunction and proposes that schizophrenic patients have abnormal dopamine-mediated brain responses to the rewarding stimuli; as a consequence, they may use substances because they enable them to temporarily increase the dopaminergic activity in their reward circuitry.[21] A variant of this, namely the overlapping neural substrates hypothesis, suggests that this

CONTACT Jean-Michel Azorin jazorin@ap-hm.fr $\Theta$ South Hospitals (Ste Marguerite), 13274 Marseille, Cedex 9, France Tel: + $33491744082 ;$ Fax: + 33491 745578

This article was originally published with errors. This version has been corrected. Please see Corrigendum (http://dx.doi.org/10.1517/14656566.2016.1132817) (c) 2015 Taylor \& Francis 
Article highlights

- Comorbid substance use is frequent among schizophrenic patients

- It is associated with poor adherence to treatment, high rates of medical comorbidity and may impact brain structures.

- There is a paucity of well-designed controlled studies for the treatment of schizophrenic symptoms in these patients.

- Randomised placebo-controlled trials are more frequent for the treatment of craving and substance intake.

- Concerning antipsychotics, given the poor adherence to medication, we recommend LAls as a first-line option, especially risperidone and derived from studies with the oral application form aripiprazole.

- Regarding anticraving agents, the best evidence is for naltrexone and disulfiram in alcohol use, and bupropion for tobacco cessation.

This box summarises key points contained in the article.

dysfunction is part of a mesocorticolimbic network dysregulation, which may be common to schizophrenia and SUD. This network dysregulation makes the executive-inhibitory regulation of motivational processes weak and the motivational response to drugs and associated stimuli overly strong, laying the groundwork for both psychotic symptoms and drug addiction.[8] However, the current hypotheses cannot adequately account for why schizophrenic patients so often have a comorbid SUD. Therefore, another hypothesis recently proposed that chronic use of typical antipsychotics could possibly induce some supersensitivity in the brain's dopamine systems, thereby enhancing the rewarding and incentive motivational effects of drugs and reward cues.[22]

To summarise, there are several hypotheses to account for the comorbidity of SUD in schizophrenia; however, they may not all have the same value. Some of them are based on theoretical assumptions whereas others have been derived from experimental data. The self-medication hypothesis is the best example of the first category, whereas the supersensitivity hypothesis belongs to the second, based on a series of studies conducted on animals.[22] The other hypotheses fall in between the two categories. Nevertheless, all have been useful to suggest new treatment strategies.

Several reviews have previously been published on the treatment of schizophrenic patients with comorbid SUD,[23-28] either focusing on antipsychotics $[29,30]$ or encompassing all psychiatric patients.[31] In the current review, we aim to focus on the pharmacological approach and are presenting an update of the randomised controlled trials (RCTs) conducted among such comorbid schizophrenic patients. These trials concern two categories of drugs. First, psychotropic agents that are also prescribed to schizophrenic patients without SUD to treat their psychotic disorder. Second, drugs used to reduce substance intake or craving that could also be indicated in patients with primary SUD. As some medications among those belonging to the first category may be efficient on both schizophrenia and SUD symptomatolgy of comorbid patients (see Section 2), we decided to also briefly review their efficacy in primary SUD. We thought that this could help understand whether the potential improvement of SUD shown with these agents in comorbid patients depended or not on their efficacy on schizophrenic symptoms. We finally address, as a special case, the treatment of substance-induced psychotic disorder.

We conducted a PubMed search of articles published between 1 January 1985 and 31 July 2015 using the following keywords: 'pharmacological treatment of schizophrenia' in combination with 'substance use', 'nicotine use', 'alcohol use', 'cannabis use', 'cocaine use', 'amphetamine use', 'stimulant use', 'opioid use', 'poly-drug use' and 'co-occurring disorder' (COD). Articles in English, German, French and Spanish were considered. Studies were only included if they contained data specific to schizophrenia spectrum disorders and/or SUD, as defined by Diagnostic and Statistical Manual of Mental Disorders (DSM) or International Classification of Diseases (ICD) criteria at the time in which the studies were conducted. There were no limitations on the methodological designs of the studies reviewed, with the exception of pharmacological trials among which only RCTs were retained for analysis. Case-control studies comparing two or more agents (retrospective or prospective) with no randomisation, case reports and cross-sectional studies were excluded. Considering the paucity of RCTs in the targeted populations, there were no limitations regarding the number or age of patients included in the studies. The review performed according to the Preferred Reporting Items for Systematic Reviews and Meta-Analysis (PRISMA) Statement.[32] Figure 1 reflects the literature search that resulted in 152 articles included in the qualitative synthesis.

\section{Antipsychotics for schizophrenic patients with SUD}

RCTs conducted in schizophrenia spectrum disorder patients with comorbid SUD are summarised in Table 1. Five studies compared first- vs. second-generation antipsychotics (FGAs vs. SGAs), four compared different SGAs, whereas six others followed a different design. 

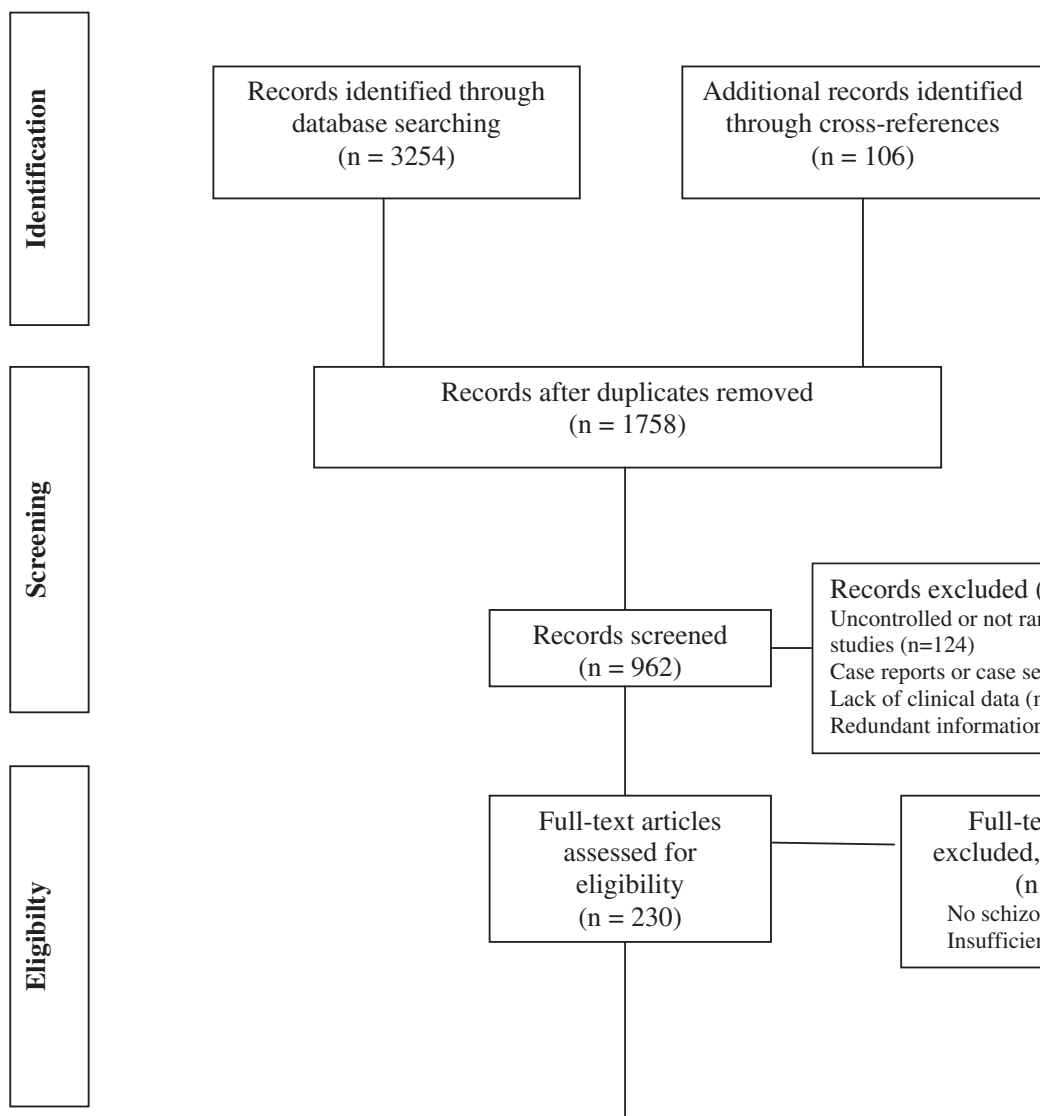

Records after duplicates removed

$(\mathrm{n}=1758)$
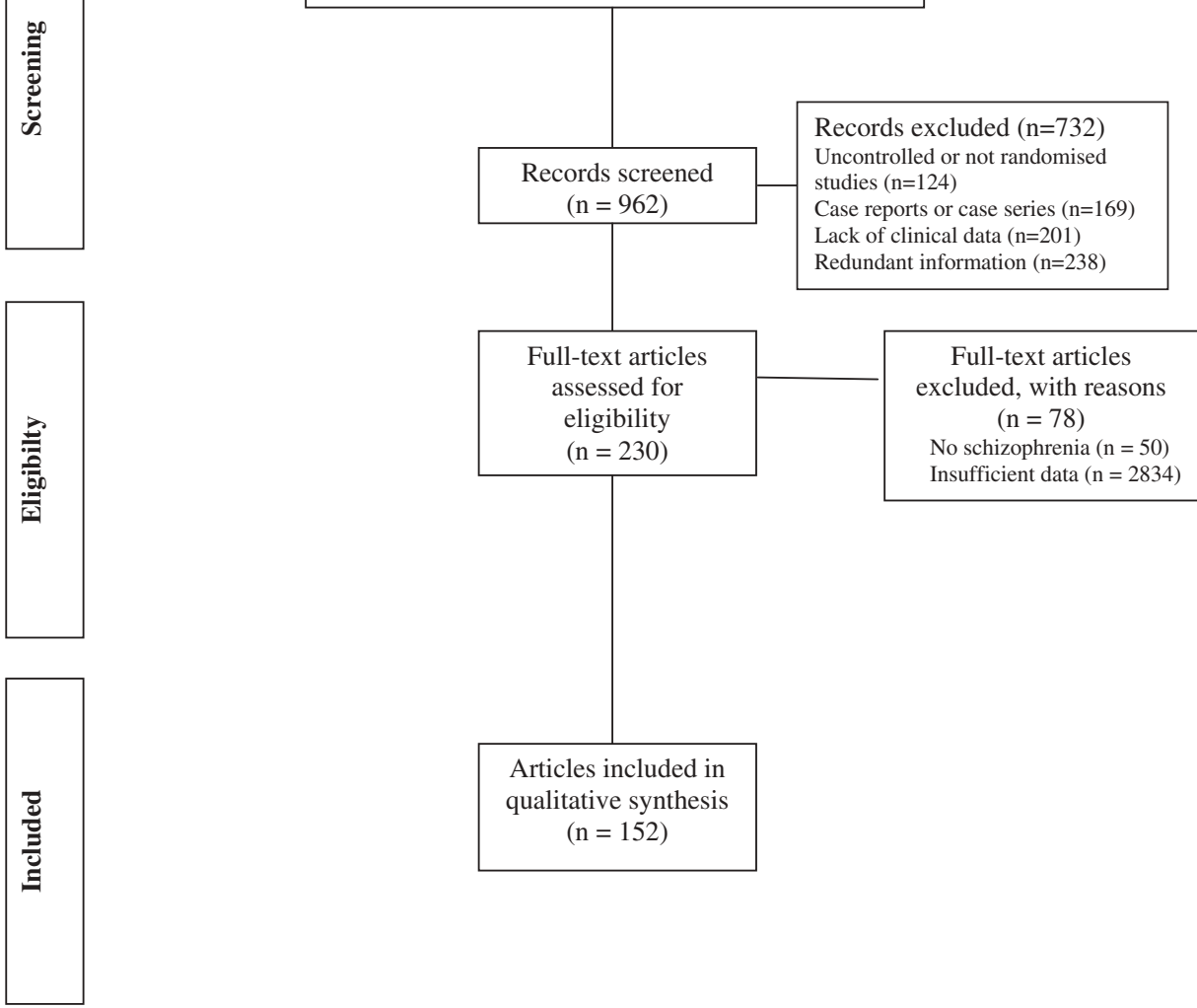

Articles included in qualitative synthesis $(\mathrm{n}=152)$

Figure 1. Preferred reporting items for systematic reviews and meta-analyses flow diagram of the literature search.

\subsection{First- vs. second-generation antipsychotics}

The first study [33] was a 12-week RCT comparing haloperidol with olanzapine for the treatment of firstepisode psychosis. After 2-14 days of washout, patients were randomly assigned to haloperidol (mean dose $4.8 \mathrm{mg} /$ day) or olanzapine (mean dose $10.2 \mathrm{mg} /$ day) medications. The study involved 262 patients; and among this sample, 97 (37\%) had a lifetime diagnosis of SUD. According to the 12-week response data, $27 \%$ of patients with SUD were responders compared with $35 \%$ of those without SUD. The response rate was quite similar in the olanzapine and the haloperidol groups.

The second study [34] was a 26-week RCT comparing haloperidol with olanzapine for the treatment of schizophrenic patients with cocaine SUD. After the screening evaluation, 24 patients were randomised either to haloperidol $(10 \mathrm{mg})$ or olanzapine (10 $\mathrm{mg}$ ) and then tapered from their own previous antipsychotic medication over the first 1 to 2 weeks of study. At the end of the trial, no significant differences were to be found between haloperidol- and olanzapine-treated patients in terms of psychosis improvement; however, the craving for cocaine was rated significantly lower by the patients treated with haloperidol.

The third study [35] was a 6-week RCT that compared haloperidol with olanzapine for the treatment of schizophrenic patients with cocaine dependence. Thirty-one patients were randomised to haloperidol (mean dose $10 \mathrm{mg} /$ day) or olanzapine (mean dose $10 \mathrm{mg} /$ day), undergoing a cue exposure procedure, 
Table 1. Studies (RCTs) of antipsychotics in patients with schizophrenia (or schizophrenia spectrum disorders) and comorbid SUD.

\begin{tabular}{|c|c|c|c|c|c|c|c|}
\hline Study (y) & Duration & Participants & $\begin{array}{c}\text { Trial } \\
\text { design }\end{array}$ & Treatment & No. of patients & $\begin{array}{l}\text { Efficacy on } \\
\text { SCZ/SCA/SCP }\end{array}$ & Efficacy on SUD \\
\hline \multicolumn{8}{|c|}{$\begin{array}{l}\text { First- vs. second-generation } \\
\text { antipsychotics }\end{array}$} \\
\hline $\begin{array}{l}\text { Green et al. } \\
\text { (2004) [33] }\end{array}$ & 12 weeks & $\begin{array}{l}\text { First-episode } \\
\text { psychosis (SCZ, } \\
\text { SCA, SCP) z with } \\
\text { and without } \\
\text { lifetime SUD }\end{array}$ & $\begin{array}{l}\text { Double- } \\
\text { blind }\end{array}$ & OLA vs. HAL & $\begin{array}{l}97 \text { with SUD } \\
165 \text { without }\end{array}$ & $\begin{array}{l}\text { OLA with SUD: response rate } \\
23 \% \text {; HAL with SUD } 31 \% \text {. } \\
\text { Patients with } \\
\text { AUD less likely to respond to } \\
\text { OLA than those without }\end{array}$ & NA \\
\hline $\begin{array}{l}\text { Sayers et al. } \\
\text { (2005) [34] }\end{array}$ & 26 weeks & $\begin{array}{l}\text { SCZ with cocaine } \\
\text { abuse }\end{array}$ & $\begin{array}{l}\text { Double- } \\
\text { blind }\end{array}$ & OLA vs. HAL & 24 & $\begin{array}{l}\mathrm{HAL}=\mathrm{OLA} \text { in reducing SAPS } \\
\text { and SANS scores }\end{array}$ & $\begin{array}{l}\mathrm{HAL}>\mathrm{OLA} \text { in reducing } \\
\text { self-reported cocaine } \\
\text { craving }\end{array}$ \\
\hline $\begin{array}{l}\text { Smelson et al. } \\
\text { (2006) [35] }\end{array}$ & 6 weeks & $\begin{array}{l}\text { SCZ with cocaine } \\
\text { dependence }\end{array}$ & $\begin{array}{l}\text { Double- } \\
\text { blind }\end{array}$ & OLA vs. HAL & 31 & $\begin{array}{l}\text { OLA }=H A L \text { in reducing } \\
\text { PANSS scores }\end{array}$ & $\begin{array}{l}\text { OLA > HAL in reducing } \\
\text { VCCQ energy scores } \\
\text { OLA }=\text { HAL on positive } \\
\text { urine toxicology }\end{array}$ \\
\hline $\begin{array}{l}\text { Rubio et al. } \\
\text { (2006) [36] }\end{array}$ & 24 weeks & SCZ with SUD & $\begin{array}{l}\text { Single- } \\
\text { blind }\end{array}$ & $\begin{array}{l}\text { RIS-LAI vs. } \\
\text { ZUC-depot }\end{array}$ & 115 & $\begin{array}{l}\text { RIS > ZUC in reducing } \\
\text { PANSS scores }\end{array}$ & $\begin{array}{l}\text { RIS }>\text { ZUC on positive } \\
\text { urine tests and on } \\
\text { adherence to the } \\
\text { substance abuse } \\
\text { management programme }\end{array}$ \\
\hline $\begin{array}{l}\text { Swartz et al. } \\
\text { (2008) [37] }\end{array}$ & 18 months & $\begin{array}{l}\text { SCZ with illicit drug } \\
\text { use }\end{array}$ & $\begin{array}{l}\text { Double- } \\
\text { blind }\end{array}$ & $\begin{array}{l}\text { OLA vs. PER } \\
\text { vs. QUE vs. } \\
\text { RIS vs. ZIP }\end{array}$ & $\begin{array}{l}634 \text { with illicit } \\
\text { drug use } \\
789 \text { without }\end{array}$ & $\begin{array}{l}\text { No significant differences } \\
\text { between treatments in time } \\
\text { to all-course treatment } \\
\text { discontinuation among illicit } \\
\text { drug users }\end{array}$ & NA \\
\hline \multicolumn{8}{|c|}{ Comparisons between SGAs } \\
\hline $\begin{array}{l}\text { Akerele and Levin } \\
\text { (2007) [38] }\end{array}$ & 14 weeks & SCZ with SUD & $\begin{array}{l}\text { Double- } \\
\text { blind }\end{array}$ & OLA vs. RIS & 28 & $\begin{array}{l}\text { OLA }=\text { RIS in reducing } \\
\text { PANSS scores }\end{array}$ & $\begin{array}{l}\text { OLA = RIS on positive } \\
\text { urine tests for both } \\
\text { cocaine and marijuana }\end{array}$ \\
\hline $\begin{array}{l}\text { van Nimwegen } \\
\text { et al. (2008) [39] }\end{array}$ & 6 weeks & $\begin{array}{l}\text { SCZ, SCA, SCP with } \\
\text { and without SUD }\end{array}$ & $\begin{array}{l}\text { Double- } \\
\text { blind }\end{array}$ & OLA vs. RIS & $\begin{array}{l}41 \text { with SUD } \\
87 \text { without }\end{array}$ & $\begin{array}{l}\text { OLA = RIS in improving SWN } \\
\text { scores }\end{array}$ & $\begin{array}{l}\text { OLA }=\text { RIS on craving and } \\
\text { reduction of mean } \\
\text { number of joints }\end{array}$ \\
\hline $\begin{array}{l}\text { Sevy et al. } \\
\text { (2011) [40] }\end{array}$ & 16 weeks & $\begin{array}{l}\text { First-episode } \\
\text { psychosis (SCZ, } \\
\text { SCA, SCP) with } \\
\text { lifetime SUD }\end{array}$ & $\begin{array}{l}\text { Double- } \\
\text { blind }\end{array}$ & OLA vs. RIS & 49 & $\begin{array}{l}\text { OLA = RIS on positive and } \\
\text { negative symptom } \\
\text { improvement }\end{array}$ & $\begin{array}{l}\text { OLA = RIS in reducing } \\
\text { cannabis and alcohol use }\end{array}$ \\
\hline $\begin{array}{l}\text { Schnell et al. } \\
(2014) \text { [41] }\end{array}$ & 12 months & $\begin{array}{l}\text { SCZ with cannabis } \\
\text { abuse/dependence }\end{array}$ & Open & CLO vs. ZIP & 30 & $\begin{array}{l}\text { CLO > ZIP in reducing } \\
\text { PANSS }\end{array}$ & $\begin{array}{l}\mathrm{CLO}=\mathrm{ZIP} \text { in reducing } \\
\text { cannabis abuse }\end{array}$ \\
\hline \multicolumn{8}{|l|}{ 0thers } \\
\hline $\begin{array}{l}\text { Mr Evoy et al. } \\
\text { (1995) [42] }\end{array}$ & 12 weeks & $\begin{array}{l}\text { Refractory SCZ } \\
\text { with nicotine use }\end{array}$ & $\begin{array}{l}\text { Double- } \\
\text { blind }\end{array}$ & $\begin{array}{l}\text { CLO (3 } \\
\text { plasma } \\
\text { ranges) }\end{array}$ & 12 & $\begin{array}{l}\text { Greater improvement with } \\
\text { the } 2 \text { higher plasma level } \\
\text { ranges }\end{array}$ & $\begin{array}{l}\text { Middle plasma level range } \\
\text { associated with } \\
\text { significantly greater } \\
\text { decline than the low } \\
\text { range }\end{array}$ \\
\hline $\begin{array}{l}\text { Mr Evoy et al. } \\
\text { (1999) [43] }\end{array}$ & 12 weeks & $\begin{array}{l}\text { Refractory SCZ } \\
\text { with and with out } \\
\text { nicotine use }\end{array}$ & $\begin{array}{l}\text { Double- } \\
\text { blind }\end{array}$ & $\begin{array}{l}\text { CLO (3 } \\
\text { plasma } \\
\text { ranges) }\end{array}$ & $\begin{array}{l}55 \text { smokers } \\
15 \text { non } \\
\text { smokers }\end{array}$ & $\begin{array}{l}\text { Greater response in smokers } \\
\text { and with the two higher } \\
\text { plasma levels ranges }\end{array}$ & $\begin{array}{l}\text { Patients assigned to the } \\
\text { medium or high serum } \\
\text { ranges had greater } \\
\text { declines in the number of } \\
\text { cigarettes smoked }\end{array}$ \\
\hline $\begin{array}{l}\text { de Leon et al. } \\
\text { (2005) [44] }\end{array}$ & $\begin{array}{l}16-48 \\
\text { weeks }\end{array}$ & $\begin{array}{l}\text { Refractory SCZ } \\
\text { with nicotine use }\end{array}$ & $\begin{array}{l}\text { Double- } \\
\text { blind }\end{array}$ & $\begin{array}{l}\text { CLO (three } \\
\text { doses) }\end{array}$ & 38 & NA & $\begin{array}{l}\text { No significant effect of } \\
\text { clozapine on smoking }\end{array}$ \\
\hline $\begin{array}{l}\text { Brown et al. } \\
\text { (2005) [45] }\end{array}$ & 12 weeks & $\begin{array}{l}\text { Psychiatric patients } \\
\text { with cocaine and } \\
\text { amphetamine use }\end{array}$ & Open & $\begin{array}{l}\text { QUE vs. } \\
\text { discontinued } \\
\text { chronic } \\
\text { typical } \\
\text { antipsychotic } \\
\text { treatment }\end{array}$ & $\begin{array}{l}24,9 \\
\text { with SCZ/SCA }\end{array}$ & $\begin{array}{l}\text { Greater improvement In } \\
\text { psychotic symptoms for } \\
\text { QUE treated patients }\end{array}$ & $\begin{array}{l}\text { Greater improvement in } \\
\text { drug craving for QUE- } \\
\text { treated patients }\end{array}$ \\
\hline $\begin{array}{l}\text { Brunette et al. } \\
\text { (2011) [46] }\end{array}$ & 12 weeks & $\begin{array}{l}\text { SCZ, SCA with } \\
\text { cannabis use }\end{array}$ & $\begin{array}{l}\text { Single- } \\
\text { blind }\end{array}$ & $\begin{array}{l}\text { CLO vs. } \\
\text { continued } \\
\text { current } \\
\text { antipsychotic } \\
\text { medication }\end{array}$ & 31 & $\begin{array}{l}\text { No difference on SCZ/SCA } \\
\text { Symptoms }\end{array}$ & $\begin{array}{l}\text { Patients switched to CLO } \\
\text { smoke } 4-5 \text { joints of } \\
\text { cannabis less per week }\end{array}$ \\
\hline $\begin{array}{l}\text { Leatherman et al. } \\
\text { (2014) [47] }\end{array}$ & 24 months & $\begin{array}{l}\text { SCZ, SCA with and } \\
\text { without substance } \\
\text { use or abuse }\end{array}$ & $\begin{array}{l}\text { Single- } \\
\text { blind }\end{array}$ & $\begin{array}{l}\text { RIS-LAI vs. } \\
\text { psychiatrist's } \\
\text { choice of oral } \\
\text { antipsychotic }\end{array}$ & 369 & $\begin{array}{l}\text { No difference on symptoms, } \\
\text { functioning, and quality of } \\
\text { life }\end{array}$ & $\begin{array}{l}\text { White patients receiving } \\
\text { LAI-RIS showed greater } \\
\text { improvement in substance } \\
\text { abuse than those on oral } \\
\text { treatment }\end{array}$ \\
\hline
\end{tabular}

Notes: RCT: randomised controlled trial; SCZ: schizophrenia; SCA: schizoaffective disorder; SCP: schizophreniform disorder; SUD: substance use disorder; NA: not assessed; AUD: alcohol use disorder; OLA: olanzapine; HAL: haloperidol; SAPS: Scale for the Assessment of Positive Symptoms; SANS: Scale for the Assessment of Negative Symptoms; PANSS: Positive and Negative Syndrome Scale; VCCQ: Voris Cocaine Craving Questionnaire; LAI: long-acting injectable; ZUC: zuclopenthixol; RIS: risperidone; SWN: Subjective Well-Being under Neuroleptics Scale; CLO: clozapine; ZIP: ziprasidone; QUE: quetiapine; PER: perphenazine. 
and assessed for psychosis and SUD. At the end of the study, individuals from the olanzapine group had a significant reduction on the energy subscale of the Voris Cocaine Craving Questionnaire compared with individuals from the haloperidol group. The olanzapine-treated group also had a lower, but not statistically significant, Positive and Negative Syndrome Scale (PANSS) General Psychopathology subscale score, and they also had fewer positive urine toxicology screens in comparison with the ones in the haloperidol group.

The fourth study [36] was a 24-week RCT comparing the efficacy of long-acting injectable (LAI) risperidone and zuclopenthixol in subjects with schizophrenia and SUD. Participants were treated with oral antipsychotics prior to starting the trial. A total of 115 subjects were enrolled: 57 were selected for risperidone treatment, while 58 were treated with zuclopenthixol. At the end of the follow-up, the risperidone group was treated with $47.2 \mathrm{mg}$ per 15 days of long-acting risperidone and $3.4 \mathrm{mg}$ daily of oral risperidone. The participants in the zuclopenthixol group received $200 \mathrm{mg}$ of zuclopenthixol-depot every 21 days and a daily oral dosage of $15 \mathrm{mg}$. Patients treated with risperidone showed better response on the PANSS, better adherence to the substance abuse management programme and presented fewer positive urine tests.

The last study [37] compared the effectiveness of five antipsychotics (olanzapine, perphenazine, quetiapine, risperidone and ziprasidone) among illicit substance users and non-users on time to treatment discontinuation, for up to 18 months. The medication doses were flexible, based on doctor's judgement. The study included 643 patients with illicit substance use and 789 without illicit use. In the first group, the mean modal daily dose was $20.0 \mathrm{mg}$ for olanzapine, $515.1 \mathrm{mg}$ for quetiapine, $3.8 \mathrm{mg}$ for risperidone and $20.4 \mathrm{mg}$ for perphenazine. No significant differences were observed between medication groups in time to treatment discontinuation among substance users. Among non-users, olanzapine-treated patients did better than those from the other groups.

\subsection{Comparisons between SGAs}

The first study [38] was a 14-week RCT comparing the efficacy of olanzapine (5-20 mg/day) with risperidone (3-9 $\mathrm{mg} /$ day) in reducing marijuana/cocaine use and craving in individuals with schizophrenia.
The study was made up of three phases: a 2-week assessment, then a 2-week cross-taper onto olanzapine/risperidone and lastly a 10-week period of maintenance on olanzapine/risperidone. At the end of the trial, the two groups were comparable in terms of improvement in PANSS scores. The proportion of cocaine-positive urines, however, decreased over time in both groups, with a greater tendency of reduction in the olanzapine group compared with the risperidone group. In the last 6 weeks, marijuana craving was more likely for the risperidone group compared to the olanzapine group, although there were no differences between the groups concerning the proportion of negative marijuana urine testing.

The second study [39] was a 6-week RCT that examined whether subjective well-being and craving for cannabis were different in schizophrenic patients treated with either olanzapine or risperidone. At the end of the study, patients had received a mean dosage of $11.1 \mathrm{mg}$ olanzapine and a mean dosage of $3.0 \mathrm{mg}$ risperidone. The study was carried out in 128 young adults with a recent onset of schizophrenia or related disorders. Both groups demonstrated a similar improvement in subjective well-being. In the comorbid cannabis-using group ( $n=41,32 \%)$, a similar decrease in craving for cannabis was to be found in both treatment conditions.

The third study [40] was a 16-week RCT comparing the efficacy of olanzapine and risperidone for the acute treatment of first-episode psychosis patients with cannabis use disorders. The study included 49 patients (28 in the olanzapine group, 21 in the risperidone group). The mean modal daily dose was $15 \pm 6 \mathrm{mg}$ for olanzapine and $4 \pm 2 \mathrm{mg}$ for risperidone. The results of the study showed that olanzapine or risperidone had a similar efficacy on psychotic symptoms and SUD.

The last study [41] was a 12-month RCT comparing the effects of clozapine and ziprasidone in patients with schizophrenia and cannabis abuse/ dependence. Thirty patients were randomised to clozapine or ziprasidone. A total of 14 patients were treated with clozapine and 16 with ziprasidone. The average daily dose of clozapine was $225 \mathrm{mg}$ (range: $50-425 \mathrm{mg}$ ), and the average dose of ziprasidone was $200 \mathrm{mg}$ (range: $80-400 \mathrm{mg}$ ). At the end of the trial, less positive symptoms, more side effects and poorer adherence to medication were associated with clozapine treatment. Cannabis use was reduced in both groups during follow-up. 


\subsection{Other studies}

Three studies [42-45] compared with approximately the same design the efficacy of three plasma ranges or doses of clozapine in the treatment of refractory schizophrenic patients with nicotine use disorder. The first two were carried out over 12 weeks, the third one over $16-48$ weeks. A total of 12 patients were included in the first,[42] 70 in the second (55 smokers, 15 non-smokers),[43] and 38 in the last study. [44] The first two studies found greater improvement of psychotic symptoms with higher plasma ranges. They also found that higher plasma ranges were associated with greater reductions in number of cigarettes actually smoked. However, the elevated plasma level of clozapine could simply be the effect of reduced smoking, due to the metabolic interaction and not an effect of higher dosage. The third study found no significant effect whatsoever for clozapine treatment on plasma cotinine levels (considered to be the most reliable biomarker for smoking decrease and abstinence) at any dose.[45]

Another 12-week study examined the effect resulting from typical antipsychotic discontinuation on cocaine and amphetamine use in patients with psychotic disorders.[45] Twenty-four patients (with nine schizophrenia or schizoaffective patients) were randomised to continue $(n=12)$ or discontinue ( $n=12)$ chronic typical antipsychotic therapy. Quetiapine was given, if necessary, for psychosis within the discontinuation group $(n=8)$. Among the eight patients in the discontinued therapy group who received quetiapine, significant improvements in psychotic symptoms and drug craving were seen, compared with the four patients in the discontinuing therapy group who received no further antipsychotic treatment. Overall, a significant reduction in drug craving was observed in patients discontinuing typical antipsychotic therapy $(n=12)$ compared with those continuing the typical antipsychotic treatment.

Another study [46] was a 12-week trial comparing the impact of clozapine with usual antipsychotic treatment on cannabis use in patients with schizophrenia and co-occurring cannabis use disorder. Thirty-one patients were randomly assigned either to switch to clozapine or to stay on the current antipsychotic treatment. A total of 15 patients were treated with clozapine and 16 with their usual treatment. The dose of antipsychotics (chlorpromazine equivalents) was $319 \pm 163.5 \mathrm{mg}$ in the clozapine group and $492 \pm 337.6 \mathrm{mg}$ in the other group. At the end of the study, symptoms and functioning were not different between both groups. However, the clozapine group demonstrated a lesser average intensity of cannabis use by approximately 4.5 joints per week.

The last study [47] was a secondary analysis of a long-term, randomised trial of patients with unstable schizophrenia; this trial found no benefit from LAI risperidone compared to oral treatment concerning the prevention or delay of psychotic hospitalisation or the clinical outcomes.[48] Patients with schizophrenia or schizoaffective disorder previously hospitalised within the past 2 years or deemed at risk for hospitalisation due to increasing psychiatric service use were randomly assigned either to LAl risperidone $(12.5-50 \mathrm{mg}$ per injection biweekly) or to the psychiatrist's own choice of oral antipsychotic medication, then patients were followed up for up to 2 years. The primary endpoint was psychiatric re-hospitalisation. The symptoms, quality of life and global functioning were assessed through blinded video-conference interviews. Substance use outcomes were assessed according to the Addiction Severity Index (ASI). Patients treated with LAI risperidone showed no superiority over the psychiatrist's own choice of oral treatment in most of clinically defined subgroups; however, White patients showed better substance use outcome than the other groups.

To summarise, several RCTs comparing FGAs vs. SGAs, or involving comparisons between SGAs, have been conducted in schizophrenic patients with SUD; if the drugs demonstrated some efficacy, it is however difficult to conclude due to the lack of a placebo arm in these studies.

\section{Antipsychotics for primary SUD}

\subsection{Cocaine and stimulants}

A double-blind comparison of flupenthixol, desipramine and placebo was conducted in a sample of extremely impaired crack cocaine users.[49] Assessments were completed for 81 subjects. Twenty-seven subjects per cell were randomised to flupenthixol, desipramine or placebo for 6 weeks. Flupenthixol was found to be superior to placebo in the restriction of cocaine use.

A recently published meta-analysis was conducted on randomised, placebo-controlled trials of antipsychotics lasting at least 2 weeks in patients with primary cocaine or psychostimulant dependence.[50] Ten studies carried out among patients with primary cocaine dependence (risperidone $=5$, olanzapine $=3$, reserpine $=2 ; n=562$ ) and four in those with amphetamine/methamphetamine dependence (aripiprazole $=4$; 
$n=179)$ were meta-analysed (14 studies, total $n=741$ ). Overall, antipsychotics did not significantly differ from placebo as far as cocaine use and cocaine or psychostimulant abstinence or even craving were concerned. Individually, however, aripiprazole was seen to be superior to the placebo regarding the Clinical Global Impression-Severity of Illness Scale (CGI-S); whereas olanzapine proved inferior to the placebo regarding cocaine craving, and risperidone proved inferior to the placebo regarding depression.

\subsection{Alcohol}

The first two studies [51,52] were conducted with tiapride, a substituted benzamide with efficacy for D2/D3 receptors, which was found to be superior to a placebo in relapse prevention and in decreasing drinking in alcoholics. Nevertheless, more recent and larger placebo-controlled trials have shown significantly more relapse with tiapride than with placebo in undifferentiated alcoholics.[53,54] Similar results were found with another benzamide, namely amisulpride.[55] One study investigated the use of flupenthixol decanoate and has found a significant increase in relapse in comparison with a placebo.[56] Compared with placebo, in individuals with the longer alleles of the DRD4 genotype, but not with the shorter alleles, olanzapine was found to reduce cue-elicited craving and drinking.[57] However, no difference between olanzapine and a placebo was found in a study that did not differentiate between subsets of alcoholics.[58]

Similarly, in one study, quetiapine was found to reduce craving and drinking over placebo in type $B$ but not type $A$ alcoholics.[59] However, a multisite clinical trial showed no efficacy for extended release quetiapine fumarate (quetiapine XR) compared with a placebo at reducing alcohol consumption in heavydrinking alcohol-dependent patients.[60] One large placebo-controlled study found aripiprazole to lower the amount of heavy alcohol consumption and alcohol dependence severity [61]; moreover, another RCT found aripiprazole to be associated with a longer abstinence time compared to naltrexone, although the latter produced larger decreases in craving.[62]

To conclude, RCTs have shown, with a few exceptions, that there was no benefit from antipsychotics in the treatment of primary SUD. This suggests that, in the vast majority of cases, their efficacy on SUD observed in comorbid patients may be dependent on their capacity to improve psychopathology.

\section{Antipsychotics for substance-induced psychotic disorders}

According to DSM-5, two characteristics may allow to differentiate substance-induced psychotic disorder from schizophrenia with SUD. Psychotic symptoms in the former do not onset during a drug-free period and do not persist during a period of sustained abstinence from substances.[63] However, as emphasised by some authors,[63] this is not always easy to apply in clinical practice. In such circumstances, and due to the lack of any validated marker that could assist diagnosis, the clinician must rely upon his own skill to perceive 'the subjective experiential core' [64] of schizophrenia.

Two RCTs $[65,66]$ were conducted to assess the efficacy of antipsychotic medication on cannabisinduced psychotic disorder. The first RCT [64] compared the efficacy of olanzapine with that of haloperidol in a 4-week-long double-blind trial. The second study [65] compared the efficacy of risperidone with that of haloperidol following a similar design. A total of 30 patients were included in each study. In both studies, there were no significant differences between either of the two arms as regards treatment for cannabis-induced psychotic disorder; nevertheless, olanzapine was associated with a lower rate of EPS compared to haloperidol.

As a conclusion, substance-induced psychotic disorders may be a special case and before initiating treatment it is rather speculative if there is no comorbidity behind the clinical picture. Nevertheless, RCTs conducted so far have shown efficacy of antipsychotics in such disorders.

\section{Antidepressants, mood stabilisers and benzodiazepines}

\subsection{Antidepressants}

Two RCTs investigated the efficacy of tricyclics (TCAs) in schizophrenic patients with SUD. $[67,68]$ The first study, conducted on a small group of patients, found some benefit of adjunctive imipramine, compared to a placebo for schizophrenic patients with comorbid cocaine use disorder, but not for those with cannabis use disorder.[67] In the second trial, administration of adjunctive desipramine with antipsychotic treatment led to reduced cocaine use compared with a placebo in a population of 80 patients. [68] The results of this trial [68] confirmed the findings of a previous controlled, but not randomised study. [69] In non-schizophrenia users, RCTs of TCAs have 
yielded inconsistent findings.[70] In the previously mentioned study, which compared the efficacy of flupenthixol, desipramine and placebo in crack cocaine users,[49] desipramine was significantly superior to a placebo in reducing cocaine use, dyscontrol over cocaine urges and craving for cocaine. Nortriptyline has displayed some efficacy for tobacco cessation in non-comorbid patients.[70] In these patients, RCTs on TCAs and selective serotonin reuptake inhibitors (SSRIs) have shown mixed benefits in the treatment of alcohol use disorder.[70]

RCTs conducted on individuals with non-comorbid stimulant use disorder showed that whereas imipramine and SSRIs had no impact on use, promising signals were observed for mirtazapine in subgroups.[70,71] Inconsistent results were observed with desipramine.[70]

\subsection{Mood stabilisers}

RCTs conducted on lithium for the treatment of patients with a primary alcohol [72] or cocaine [73] use disorder did not demonstrate any beneficial effect. If anticonvulsants have shown efficacy in the treatment of withdrawal symptoms, especially those concerning alcohol,[70] such efficacy has not been proved for the treatment of dependence, despite some promising results for topiramate in cocaine dependence.[70]

\subsection{Benzodiazepines}

The efficacy of benzodiazepines was shown in RCTs for the treatment of withdrawal symptoms, especially those concerning alcohol.[70]

In summary, RCTs conducted on schizophrenic patients with SUD showed the efficacy of TCAs such as imipramine and desipramine for the treatment of cocaine use. In these trials, TCAs were used as adjunctive treatment to antipsychotics. As far as anticonvulsants and benzodiazepines are concerned, they may be efficient for the treatment of alcohol withdrawal symptoms. It remains unclear, based on available evidence, whether antidepressants, mood stabilisers and benzodiazepines have a specific effect on SUD in comorbid patients, unlinked to their efficacy on schizophrenic symptoms.

\section{Addiction pharmacotherapy for schizophrenic patients with SUD}

RCTs of anticraving agents conducted in schizophrenic patients with comorbid SUD are summarised in Table 2 . Addiction pharmacotherapy evaluated among patients with schizophrenia or schizoaffective disorder mainly consists of nicotine replacement treatment, varenicline, bupropion and naltrexone, with few or no RCTs on other addictions.

Table 2. Studies (RCTs) of anticraving agents in patients with schizophrenia (or schizophrenia spectrum disorders) and comorbid SUDs.

\begin{tabular}{|c|c|c|c|c|c|c|c|}
\hline Study & Duration & Participants & Trial design & Treatment & $\begin{array}{l}\text { No. of } \\
\text { patients }\end{array}$ & $\begin{array}{l}\text { Efficacy on } \\
\text { SCZ/SCA/SCP }\end{array}$ & Efficacy on SUD \\
\hline $\begin{array}{l}\text { Petrakis et al.. } \\
\text { (2004) [74] }\end{array}$ & 12 weeks & $\begin{array}{l}\text { SCZ, SCA with } \\
\text { alcohol } \\
\text { dependence }\end{array}$ & $\begin{array}{l}\text { Double-blind for } \\
\text { NAL }\end{array}$ & NAL vs. PLA & 31 & $\begin{array}{l}\text { NAL did not affect } \\
\text { symptoms of SCZ }\end{array}$ & $\begin{array}{l}\text { NAL > PLA in decreasing } \\
\text { drinking days, heavy drinking } \\
\text { days and craving }\end{array}$ \\
\hline $\begin{array}{l}\text { Petrakis et al. } \\
(2005,2006) \\
{[75,76]}\end{array}$ & 12 weeks & $\begin{array}{l}\text { SCZ, SCA, } \\
\text { BIP, other } \\
\text { axis I disorder } \\
\text { with alcohol } \\
\text { dependence }\end{array}$ & $\begin{array}{l}\text { Double-blind for } \\
\text { NAL, open for } \\
\text { DIS }\end{array}$ & $\begin{array}{l}\text { NAL vs. PLA } \\
\text { vs. DIS and } \\
\text { NAL vs. DIS } \\
\text { and PLA }\end{array}$ & $\begin{array}{l}66 \\
\text { psychotic } \\
\text { disorder }(18 \\
\text { SCZ + SCA) } \\
\text { among } 251 \\
\text { veterans. }\end{array}$ & $\begin{array}{l}\text { No significant change in } \\
\text { the PANSS scale }\end{array}$ & $\begin{array}{l}\text { NAL + DIS = NAL = DIS > PLA } \\
\text { in increasing the number of } \\
\text { consecutive days of abstinence, } \\
\text { decreasing the number of } \\
\text { heavy drinking days of SCZ } \\
\text { patients }\end{array}$ \\
\hline $\begin{array}{l}\text { Ralevski et al. } \\
\text { (2011) [77] }\end{array}$ & 12 weeks & $\begin{array}{l}\text { SCZ spectrum } \\
\text { disorders with } \\
\text { alcohol } \\
\text { dependence }\end{array}$ & Double-blind & $\begin{array}{l}\text { Acamprosate } \\
\text { vs. PLA }\end{array}$ & 23 & $\begin{array}{l}\text { Improvement of SCZ } \\
\text { symptoms in both } \\
\text { groups with no } \\
\text { significant difference } \\
\text { between groups }\end{array}$ & $\begin{array}{l}\text { Improvement of drinking in } \\
\text { both groups with no significant } \\
\text { difference between groups }\end{array}$ \\
\hline $\begin{array}{l}\text { Meszaros et al. } \\
\text { (2013) [84] }\end{array}$ & 8 weeks & $\begin{array}{l}\text { SCZ, SCA with } \\
\text { nicotine and } \\
\text { alcohol } \\
\text { dependence }\end{array}$ & Double-blind & VAR vs. PLA & 10 & $\begin{array}{l}\text { No significant change in } \\
\text { the PANSS scale and no } \\
\text { improvement in } \\
\text { cognition tests }\end{array}$ & $\begin{array}{l}\text { VAR }=\text { PLA in reduction of } \\
\text { cigarettes per day and number } \\
\text { of standard alcohol drinks. }\end{array}$ \\
\hline $\begin{array}{l}\text { Weiner et al. } \\
\text { (2012) [94] }\end{array}$ & 12 weeks & $\begin{array}{l}\text { SCZ, SCA with } \\
\text { nicotine } \\
\text { dependence }\end{array}$ & Double-blind & BUP vs. PLA & 32 & $\begin{array}{l}\text { No significant change in } \\
\text { the neuropsychological } \\
\text { performance }\end{array}$ & $\begin{array}{l}\text { BUP }=\text { PLA on the primary } \\
\text { outcome ( } 4 \text { weeks' sustained } \\
\text { abstinence over the last } 4 \\
\text { weeks) }\end{array}$ \\
\hline $\begin{array}{l}\text { Allen et al. } \\
\text { (2011) [80] }\end{array}$ & 24 hours & $\begin{array}{l}\text { SCZ with } \\
\text { agitation and } \\
\text { nicotine } \\
\text { dependence }\end{array}$ & Double-blind & $\begin{array}{l}\text { Nicotine- } \\
\text { patch vs. PLA }\end{array}$ & 40 & $\begin{array}{l}\text { Agitation diminished } \\
\text { over time in both } \\
\text { groups but did not } \\
\text { reach statistical } \\
\text { significance }\end{array}$ & NA \\
\hline
\end{tabular}


Table 2. (Continued).

\begin{tabular}{|c|c|c|c|c|c|c|c|}
\hline Study & Duration & Participants & Trial design & Treatment & $\begin{array}{l}\text { No. of } \\
\text { patients }\end{array}$ & $\begin{array}{l}\text { Efficacy on } \\
\text { SCZ/SCA/SCP }\end{array}$ & Efficacy on SUD \\
\hline $\begin{array}{l}\text { Chen et al. } \\
\text { (2013) [79] }\end{array}$ & 8 weeks & $\begin{array}{l}\text { SCZ, SCA with } \\
\text { nicotine } \\
\text { dependence }\end{array}$ & Double-blind & $\begin{array}{l}\text { Nicotine- } \\
\text { patch (high } \\
\text { dose vs. low } \\
\text { dose) }\end{array}$ & 184 & $\begin{array}{l}\text { No differences in } \\
\text { antipsychotic-induced } \\
\text { EPSs between groups }\end{array}$ & NRT high dose $=$ NRT low dose \\
\hline $\begin{array}{l}\text { Chou et al. } \\
\text { (2004) [78] }\end{array}$ & 8 weeks & $\begin{array}{l}\text { SCZ with } \\
\text { nicotine } \\
\text { dependence }\end{array}$ & Open & $\begin{array}{l}\text { Nicotine- } \\
\text { patch vs. PLA }\end{array}$ & 68 & NA & $\begin{array}{l}\text { NRT > PLA in nicotine } \\
\text { dependence, the number of } \\
\text { cigarettes smoked per day and } \\
\text { the expired carbon monoxide }\end{array}$ \\
\hline $\begin{array}{l}\text { Evins et al. } \\
\text { (2001) [89] }\end{array}$ & 12 weeks & $\begin{array}{l}\text { SCZ with } \\
\text { nicotine } \\
\text { dependence }\end{array}$ & $\begin{array}{l}\text { Pilot study, } \\
\text { double-blind }\end{array}$ & $\begin{array}{l}\text { BUP + CBT } \\
\text { vs. PLA + CBT }\end{array}$ & 18 & $\begin{array}{l}\text { Improvement in } \\
\text { negative symptoms and } \\
\text { greater stability of } \\
\text { psychotic and } \\
\text { depressive symptoms } \\
\text { with BUP }\end{array}$ & $\begin{array}{l}\text { BUP }+ \text { CBT > PLA + CBT in } \\
\text { reduction of exhaled carbon } \\
\text { monoxide }\end{array}$ \\
\hline $\begin{array}{l}\text { Evins et al. } \\
\quad(2005)[92,93]\end{array}$ & 12 weeks & $\begin{array}{l}\text { SCZ, SCA with } \\
\text { nicotine } \\
\text { dependence }\end{array}$ & Double-blind & $\begin{array}{l}\text { BUP + CBT } \\
\text { vs. PLA + CBT }\end{array}$ & 53 & $\begin{array}{l}\text { No worsening of clinical } \\
\text { symptoms and a trend } \\
\text { towards improvement } \\
\text { in depressive and } \\
\text { negative symptoms } \\
\text { with BUP }\end{array}$ & $\begin{array}{l}\mathrm{BUP}+\mathrm{CBT}>\mathrm{PLA}+\mathrm{CBT} \text { in } \\
\text { abstinence rates }\end{array}$ \\
\hline $\begin{array}{l}\text { Evins et al. } \\
\text { (2007) [95] }\end{array}$ & 12 weeks & $\begin{array}{l}\text { SCZ with } \\
\text { nicotine } \\
\text { dependence }\end{array}$ & Double-blind & $\begin{array}{l}\text { BUP + NRT } \\
\text { vs. PLA + NRT }\end{array}$ & 51 & $\begin{array}{l}\text { No effects of study } \\
\text { medication on } \\
\text { psychiatric symptoms }\end{array}$ & $\begin{array}{l}\text { BUP + NRT > PLA + NRT in } \\
\text { smoking reduction }\end{array}$ \\
\hline $\begin{array}{l}\text { Evins et al. } \\
\text { (2014) [85] }\end{array}$ & 52 weeks & $\begin{array}{l}\text { SCZ, BIP with } \\
\text { nicotine } \\
\text { dependence } \\
\text { but abstinent }\end{array}$ & $\begin{array}{l}\text { Open until } 12 \\
\text { weeks then } \\
\text { double-blind }\end{array}$ & VAR vs. PLA & $\begin{array}{l}77 \mathrm{SCZ}, \\
10 \mathrm{BIP}\end{array}$ & $\begin{array}{l}\text { No new or worsening } \\
\text { neuropsychiatric } \\
\text { symptoms }\end{array}$ & VAR $>$ PLA in abstinence rates \\
\hline $\begin{array}{l}\text { Fatemi et al. } \\
\text { (2005) [91] }\end{array}$ & 8 weeks & $\begin{array}{l}\text { SCZ, SCA with } \\
\text { nicotine } \\
\text { dependence }\end{array}$ & $\begin{array}{l}\text { Double-blind, } \\
\text { cross-over }\end{array}$ & BUP vs. PLA & 10 & $\begin{array}{l}\text { No change in the PANSS } \\
\text { and SAPS scores }\end{array}$ & $\begin{array}{l}\text { BUP }=\text { PLA in number of } \\
\text { cigarettes per day }\end{array}$ \\
\hline $\begin{array}{l}\text { Fatemi et al. } \\
\text { (2013) [83] }\end{array}$ & 12 weeks & $\begin{array}{l}\text { SCZ, SCA with } \\
\text { nicotine } \\
\text { dependence }\end{array}$ & Double-blind & $\begin{array}{l}\text { VAR vs. BUP } \\
\text { vs. PLA }\end{array}$ & 24 & $\begin{array}{l}\text { In the VAR group, } \\
\text { positive correlations } \\
\text { between serum cotinine } \\
\text { levels and BPRS score, } \\
\text { BPRS positive } \\
\text { symptoms, SAPS score }\end{array}$ & $\begin{array}{l}\text { VAR }=\text { BUP }=\text { PLA in number of } \\
\text { cigarettes per day, serum or } \\
\text { urine cotinine or exhaled } \\
\text { carbon monoxide }\end{array}$ \\
\hline $\begin{array}{l}\text { George et al. } \\
(2002)[90]\end{array}$ & 10 weeks & $\begin{array}{l}\text { SCZ, SCA with } \\
\text { nicotine } \\
\text { dependence }\end{array}$ & Double-blind & BUP vs. PLA & 32 & $\begin{array}{l}\text { BUP significantly } \\
\text { reduced negative } \\
\text { symptoms. No change } \\
\text { on positive and } \\
\text { depressive (Beck) } \\
\text { symptoms }\end{array}$ & $\begin{array}{l}\text { BUP > PLA in abstinence rates, } \\
\text { exhaled carbon monoxide, } \\
\text { number of cigarettes per day }\end{array}$ \\
\hline $\begin{array}{l}\text { George et al. } \\
(2008)[96]\end{array}$ & 10 weeks & $\begin{array}{l}\text { SCZ, SCA with } \\
\text { nicotine } \\
\text { dependence }\end{array}$ & Double-blind & $\begin{array}{l}\text { BUP + NRT } \\
\text { vs. PLA + NRT }\end{array}$ & 58 & $\begin{array}{l}\text { No change in the PANSS } \\
\text { and Beck Depression } \\
\text { Inventory scores }\end{array}$ & $\begin{array}{l}\text { BUP }+N R T=P L A+N R T \text { for the } \\
\text { endpoint abstinence }\end{array}$ \\
\hline $\begin{array}{l}\text { Kelly et al. } \\
\text { (2008) [97] }\end{array}$ & 12 weeks & $\begin{array}{l}\text { SCZ, SCA with } \\
\text { nicotine } \\
\text { dependence }\end{array}$ & Double-blind & GAL vs. PLA & 43 & NA & $\begin{array}{l}\text { GAL = PLA in cigarette smoking } \\
\text { and dependency score }\end{array}$ \\
\hline $\begin{array}{l}\text { Weinberger et al. } \\
\text { (2007) [98] }\end{array}$ & 3 daysx3 & $\begin{array}{l}\text { SCZ or normal } \\
\text { control with } \\
\text { nicotine } \\
\text { dependence }\end{array}$ & $\begin{array}{l}\text { Double-bind, } \\
\text { counterbalanced }\end{array}$ & MEC vs. PLA & 60 & $\begin{array}{l}\text { No change in psychiatric } \\
\text { symptoms }\end{array}$ & $\begin{array}{l}\text { MEC = PLA in indices of } \\
\text { smoking or cigarette } \\
\text { consumption during } \\
\text { reinstatement }\end{array}$ \\
\hline $\begin{array}{l}\text { Weiner et al. } \\
\text { (2011) [81] }\end{array}$ & 12 weeks & $\begin{array}{l}\text { SCZ, SCA with } \\
\text { nicotine } \\
\text { dependence }\end{array}$ & Double-blind & VAR vs. PLA & 9 & $\begin{array}{l}\text { No difference between } \\
\text { the groups }\end{array}$ & VAR $=$ PLA in abstinence rates \\
\hline $\begin{array}{l}\text { Williams et al. } \\
\text { (2012) [82] }\end{array}$ & 12 weeks & $\begin{array}{l}\text { SCZ, SCA with } \\
\text { nicotine } \\
\text { dependence }\end{array}$ & Double-blind & VAR vs. PLA & 127 & $\begin{array}{l}\text { No difference between } \\
\text { the groups }\end{array}$ & VAR $>$ PLA in abstinence rates \\
\hline
\end{tabular}

Notes: NAL: naltrexone; BUP: bupropion; DIS: disulfiram; CBT: cognitive behaviour therapy; PLA: placebo; VAR: varenicline; NRT: nicotine replacement therapy; MEC: mecamylamine; GAL: galantamine; SCZ: schizophrenia; SCA: schizoaffective disorder; BIP: bipolar disorder; NA: not assessed.

\subsection{Naltrexone}

Two RCTs were conducted to assess the benefit of naltrexone in patients with alcohol dependence and schizophrenia.[74,76]
The first study [74] was a 12-week RCT comparing naltrexone with placebo. The study involved 31 patients randomised to receive naltrexone $50 \mathrm{mg}$ or placebo in a double-blind design. The primary 
outcome was the frequency and quantity of alcohol use. At the end of the trial, naltrexone significantly decreased alcohol use, the number of heavy drinking days and craving (based on the Tiffany Craving Questionnaire) compared with the placebo. All patients reported side effects, with dry mouth being the most frequent one (48\%), but none reached significance.

The second study $[75,76]$ was a 12 -week RCT comparing four treatment groups. A total of 254 patients with alcohol dependence were randomised to naltrexone alone, placebo alone, disulfiram and naltrexone, or disulfiram and placebo. Only the dispensing of naltrexone and placebo was double-blind. The primary outcome was the measuring of alcohol intake based on the Timeline Follow-Back interview. Of the 251 patients included in the study, only 66 had psychotic spectrum disorder, and among them 18 met the criteria for schizophrenia $(n=11)$ or schizoaffective disorders $(n=7)$. The other patients met criteria for major depression, post-traumatic stress disorder, bipolar disorder (BIP) and cocaine dependence. At the end of the study, patients with psychotic spectrum disorders and assigned either to naltrexone $50 \mathrm{mg}$ or to disulfiram $250 \mathrm{mg}$ reported significantly fewer total heavy drinking days, as well as more consecutive days of abstinence when compared with placebo-treated patients. Interestingly, there were no significant differences between naltrexone and disulfiram and no advantage in the combination vs. an active compound alone. Furthermore, there was no effect on the Obsessive Compulsive Drinking and Abstinence scale (OCDS).

\subsection{Acamprosate}

Only one RCT was conducted to assess the efficacy of acamprosate in patients with schizophrenia and alcohol dependence.[77] The study compared acamprosate with placebo in a 12-week duration trial. Twenty-three schizophrenia spectrum disorder patients with comorbid alcohol dependence were randomised to receive acamprosate or placebo in a double-blind design. At the end of the trial, schizophrenic symptoms as well as alcohol intake were significantly improved, but no difference was observed between acamprosate and placebo. The main study limitation was the lack of control for psychotropic medications.

\subsection{Nicotine replacement therapy (patch)}

Three studies were conducted to assess the effect of nicotine replacement therapy in smokers with schizophrenia.[78-80]
The first study [78] compared nicotine replacement therapy with a placebo for smoking cessation in a longitudinal open design. Sixty-eight subjects were randomly assigned to the nicotine replacement therapy group ( $n=26)$ or to placebo group $(n=42)$ for 8 weeks. The outcomes assessed were the Fagerstrom tolerance questionnaire, the number of cigarettes per day, the exhaled carbon monoxide level and the abstinence rates. A significant decrease in nicotine dependence, exhaled carbon monoxide level and number of cigarettes per day was demonstrated in the nicotine replacement therapy group compared with the placebo group. The point prevalence rates of abstinence seemed higher in the nicotine replacement therapy group than in the placebo group but no statistical test was provided.

The second study [79] was an 8-week RCT comparing different doses of nicotine replacement therapy in longterm hospitalised schizophrenic patients who intended to reduce or stop smoking. In one group, patients were assigned to nicotine replacement therapy, either $31.2 \mathrm{mg} /$ day for the first 4 weeks then $20.8 \mathrm{mg} /$ day for the following 4 weeks, or $20.8 \mathrm{mg} /$ day during the 8 weeks. Smoking reduction was the primary outcome, as defined by change in the self-reported number of cigarettes smoked. The study was carried out in 184 patients with chronic institutionalised schizophrenia (mean length of current hospitalisation was 8.7 years). The two groups showed no significant differences in nicotine dependence, exhaled carbon monoxide levels or 7-day point prevalence of abstinence $(1.1 \%$ in the high-dose nicotine replacement therapy group vs. $4.3 \%$ in the low-dose nicotine replacement therapy group).

The last study [80] was conducted to evaluate the effect of nicotine replacement therapy on agitation in smokers with schizophrenia in a 24-hour RCT. Forty patients were screened for agitation using the PANSS and for nicotine dependence. They were randomly assigned to either a $21 \mathrm{mg}$ transdermal patch or placebo. The primary outcome was the Agitated Behaviour Scale at baseline and at 4 and 24 hours. The change in the Agitated Behaviour Scale scores did not reach a statistical difference even though agitation decreased over time in all patients.

\subsection{Varenicline}

Five studies were conducted to assess the effect of varenicline for smoking cessation or reduction in patients with schizophrenia disorder.[81,85] A recent meta-analysis [86] included seven RCTs, five of which were used for evaluation of smoking cessation. Among these five RCTs, they included a study designed to investigate the effect of varenicline on biomarkers associated with schizophrenia, such as 
P50 sensory gating and eye-tracking.[87] We decided not to comment on this study, because the dose used was half the dose recommended for smoking cessation. This meta-analysis also included an 8-week, double-blind, placebo-controlled RCT designed to evaluate the effect of varenicline on cognitive impairments in schizophrenic patients.[88] However, this RCT did not clearly report the data on smoking status during and at the end of the study. It seems that these results were to be published later so we did not include this RCT either in Table 2. Meanwhile, no difference was found in the abstinence rate between varenicline and the placebo.

The first study [81] evaluated the effect of varenicline in a 12-week, double-blind, placebo-controlled RCT. Nine patients were randomised to varenicline $(1 \mathrm{mg}$ po bid) or placebo. The primary outcome, defined as sustained abstinence at the end of the study, was achieved by three of four varenicline patients and none of the four placebo patients, but the difference between the groups was not significant.

The second study [82] compared varenicline with a placebo in patients with schizophrenia or schizoaffective disorder for smoking cessation in a 12-week RCT. Abstinence was defined at the end of the study and verified with exhaled carbon monoxide. Varenicline significantly increased the abstinence rate (19\% vs. $4.7 \%)$ without more side effects or any change in schizophrenic symptoms compared to the placebo.

The third study [83] compared varenicline with bupropion and a placebo in patients with schizophrenia or schizoaffective disorder for smoking reduction in a 12-week $\mathrm{RCT}$. The 24 patients enrolled in the study were randomised to varenicline (1 $\mathrm{mg}$ po bid), bupropion ( $150 \mathrm{mg}$ po bid) or a placebo. No significant reduction was observed in the number of cigarettes smoked or exhaled carbon monoxide between the three parallel groups.

The fourth study [84] compared varenicline with a placebo in patients with schizophrenia and co-occurring nicotine and alcohol dependence in an 8-week RCT. The primary outcomes were nicotine and alcohol use assessed by the Timeline Follow-Back. Among the 10 patients randomised, only four completed the study, which was terminated owing to slow recruitment and high dropout rate (50\%). The amount of cigarettes smoked and the number of standard alcohol drinks decreased in the varenicline group compared with the placebo group without, however, reaching significance.

The last study [85] was focused on relapse prevention with varenicline following smoking cessation among patients with schizophrenia and BIP. The study design was a 12-week open-label study with varenicline and cognitive behavioural therapy followed by a double- blind, placebo-controlled RCT up to week 52. Of the 247 patients selected, only 87 met the abstinence criteria in order to enter the prevention trial (77 with schizophrenia plus 10 with BIP). The patients were randomly assigned to varenicline (1 $\mathrm{mg}$ po bid) or placebo. The primary outcome was the 7-day abstinence rate at the end of the study. At the end of the study, the varenicline group had a prevalence abstinence rate significantly higher than that of the placebo group $(60 \%, 24 / 40$ vs. $19 \%, 9 / 47)$. When schizophrenia and BIP patients were analysed separately, the treatment effect remained significant.

\subsection{Bupropion}

Five studies evaluated the effect of bupropion for smoking cessation in schizophrenic patients.

The first study [89] compared bupropion (150 mg/ day) with a placebo in a double-blind RCT. All subjects $(n=18)$ participated in nine weekly sessions of cognitive behavioural therapy. The primary outcome was point prevalence tobacco-abstinence or significant reduction in cigarette consumption at 12 weeks. Smoking reduction was defined as a $50 \%$ decrease in the number of cigarettes smoked per day relative to the baseline plus a $30 \%$ reduction of exhaled carbon monoxide. At the end of the study, three patients on bupropion and one on placebo achieved abstinence. The patients assigned to bupropion significantly decreased the level of exhaled carbon monoxide compared to the placebo. Bupropion treatment was also associated with a significantly lower Brief Psychiatric Rating Scale (BPRS) total score than the placebo group.

The second study [90] was a 10-week RCT comparing bupropion with placebo in 32 schizophrenic patients with nicotine dependence and a strong desire to stop smoking. Patients were randomised to bupropion (150 mg po bid) or a matching placebo in a doubleblind trial. The main outcome was a 7-day point prevalence of smoking abstinence rate determined by selfreport during the last 7 days of the study. Patients in the bupropion group were significantly more numerous in achieving the trial endpoint of smoking abstinence than those in the placebo group (8/16 vs. $2 / 16)$. Exhaled carbon monoxide levels and self-reported cigarettes smoked per day also significantly decreased in the bupropion group vs. placebo group.

The third study [91] compared bupropion with a placebo in smoking reduction in patients with schizophrenia in an 8-week, double-blind, cross-over RCT. The study consisted of two phases of 21 days separated by a 1-week washout. A total of nine patients were included in the study. At the end of the trial, no difference was observed in the number of cigarettes smoked 
per day. A trend towards a reduction of exhaled carbon monoxide levels, urine cotinine and nicotine metabolites was observed.

The fourth study $[92,93]$ was a 12 -week-RCT comparing bupropion ( $150 \mathrm{mg} /$ day) with a placebo for smoking cessation in schizophrenic patients. All patients took part in a 12-session cognitive behavioural therapy. The main outcome was 7-day point prevalence abstinence in the week after the quitting date and at the end of the study. The bupropion group had a higher probability of achieving the trial endpoint at the end of the study than the placebo group ( $4 / 25$ vs. $0 / 28)$. However, the effect of bupropion did not persist at 3 months after the end of the study.

The last study [94] compared bupropion with a placebo for smoking cessation in 32 patients with schizophrenia in a 12-week double-blind RCT. The study began with a group support programme (for 9 weeks). At the end of week 2, the medication was started, $150 \mathrm{mg}$ once daily for 3 days, then twice daily up until the end of the trial. Nicotine gum was offered to all patients on quit day but none used it. The main outcome was 4 weeks of abstinence over the last 4 weeks of the study. At the end of the trial, there was no difference in the abstinence rates between bupropion- and placebo-treated patients.

\subsection{Bupropion added to nicotine replacement therapy}

Two RCTs compared bupropion and a placebo combined with nicotine replacement therapy for smoking cessation in schizophrenic patients. $[95,96]$

The first study [95] involved 51 patients in a 12-week double-blind RCT. The patients were randomly assigned to bupropion (150 $\mathrm{mg}$ ) or a placebo once daily for 7 days then twice daily for 11 weeks. After the quit date, a nicotine patch was supplied at $21 \mathrm{mg} /$ day for 4 weeks, $14 \mathrm{mg} /$ day for 2 weeks and $7 \mathrm{mg} /$ day for 2 weeks. Nicotine gum ( $2 \mathrm{mg}$ ) was delivered on an "as needed" basis, with up to $18 \mathrm{mg} /$ day. All patients participated in a 12-session weekly smoking cessation group programme. The primary outcome was a 7-day point prevalence of $50-100 \%$ smoking reduction at the end of the study. At the end of the study, bupropion-treated patients were significantly more likely to achieve a $50 \%$ or greater reduction in smoking compared with placebo-treated patients ( $60 \%$ vs. $31 \%$ ).

The second study [96] also compared bupropion and a placebo combined with nicotine replacement therapy for smoking cessation in schizophrenia. The study consisted of a 10-week, double-blind RCT with 58 patients.
Bupropion or placebo treatment was initiated at $150 \mathrm{mg}$ qd for 3 days and then increased to $150 \mathrm{mg}$ po bid until the end of the study. Nicotine replacement therapy was started on the quit date for all patients. The main outcome was the abstinence rate as defined by the Timeline Follow-Back assessment combined with exhaled carbon monoxide levels $<10 \mathrm{ppm}$. At the end of the study, patients on bupropion treatment were more likely to achieve the trial endpoint, but there was no statistical group difference. However, significant effects of bupropion added to nicotine were described on short-term abstinence compared to the placebo.

\subsection{Galantamine}

A 12-week RCT [97] was conducted to evaluate the effect of galantamine on smoking in schizophrenic patients. Galantamine, an acetylcholinesterase inhibitor, or placebo was randomly assigned to 43 smokers. Galantamine treatment had no significant effect on exhaled carbon monoxide levels, and the nicotine dependence score (Fagerstrom test for nicotine dependence) worsened.

\subsection{Mecamylamine}

A study compared the effect of mecamylamine on cigarette smoking in schizophrenic patients and control smokers[98] in a randomised counterbalanced clinical trial. Mecamylamine, a nicotinic acetylcholine receptor antagonist, was randomly assigned at 0,5 or $10 \mathrm{mg} /$ day for 3 days/ week over a period of 3 weeks. The outcomes were assessed at baseline, after an overnight abstinence and after smoking reinstatement. The treatment did not change the smoking consumption during the smoking reinstatement.

\subsection{Other agents}

Two other small RCTs vs. placebo (not listed in Table 2) evaluated the efficacy of topiramate [99] and atomoxetine [100] for tobacco cessation in schizophrenia. No change was found in either study, either for tobacco use or psychiatric symptoms.

To summarise, RCTs showed some benefits with naltrexone and disulfiram for the treatment of alcohol use disorder in schizophrenic patients. A meta-analysis conducted by Tsoi et al. [101] in 2013 concluded that there was little evidence for a beneficial effect of nicotine replacement therapy in schizophrenic patients with tobacco use disorder. However, a beneficial effect was found with bupropion. There was also no evidence of benefits in the 
few trials of other pharmacological therapies. The efficacy of varenicline for tobacco cessation was not evaluated in the meta-analysis by Tsoi et al.,[101] but it was in another meta-analysis by Kishi and Iwata.[86] The latter concluded that varenicline was not superior to a placebo for smoking cessation in people with schizophrenia. There are no published studies of RCT for other anticraving agents in the population of schizophrenic patients with SUD.

\section{Conclusions}

SUD among schizophrenic patients is common and frequently associated with poor outcome. Among the different factors responsible for this, high levels of medical comorbidity and lack of adherence to treatment may be particularly relevant. There is a dearth of rigorously controlled studies targeting such patients. However, the results of RCTs suggest: (1) a trend in favour of SGAs vs. FGAs; (2) an additional efficacy of imipramine and desipramine for cocaine use; (3) a benefit from some of the medications specifically prescribed for primary SUD (mainly naltrexone and disulfiram for alcohol dependence, and bupropion for tobacco cessation). Few, if any, of the antipsychotic drugs, seem to have a clear effect on substance use in primary SUD. A large number of studies have included patients with any kind of SUD, so that we do not have a clear idea of the efficacy of medications on specific SUDs. This may be particularly true for schizophrenia medications (see Table 3). Furthermore, no RCTs have been conducted in comorbid patients with only amphetamine, heroin or opioid use disorder. From a regulatory standpoint, many medications are approved by drug agencies for the treatment of schizophrenia, only a few are approved for the treatment of SUD, whereas none are approved for the treatment of comorbid conditions. Hence, there is a need for well-designed, randomised controlled studies among schizophrenic patients with comorbid SUD, including a sufficient number of patients with specific SUDs, a placebo arm and with an appropriate trial duration. In particular, studies comparing LAls with their oral formulation may be suitable. This need appears to be especially urgent for drugs such as aripiprazole due to the existence of a depot formulation, and their potential efficacy in primary SUD. Drugs with newer mechanisms of action, such as cannabidiol, or strategies based on better knowledge of brain circuits involved in addiction and schizophrenia[102] also deserve further investigation.
Table 3. Efficacy of medications (RCTs) in schizophrenia (or schizophrenia spectrum disorders) patients by comorbid SUD.

\begin{tabular}{|c|c|c|}
\hline SUD & Medications & Efficacy in RCTs \\
\hline \multirow[t]{8}{*}{ Alcohol } & Naltrexone & $\begin{array}{l}2 \text { RCTs [74-76] } \\
\text { Efficacy on SUD in both [74-76] } \\
\text { No effect on SCZ in both [74-76] }\end{array}$ \\
\hline & Disulfiram & 1 RCT [75-76] \\
\hline & & Efficacy on SUD [75-76] \\
\hline & & No effect on SCZ [75-76] \\
\hline & Acamprosate & 1 RCT [77] \\
\hline & & Efficacy on SUD [77] \\
\hline & & Efficacy on SCZ [77] \\
\hline & & But no difference vs. PLA [77] \\
\hline \multirow[t]{18}{*}{ Nicotine } & Clozapine & 3 RCTs [42-44] \\
\hline & & $\begin{array}{l}\text { Efficacy on SUD in 2,[42,43] no efficacy } \\
\text { in } 1[44]\end{array}$ \\
\hline & & Efficacy on SCZ in 2,[42,43] efficacy NA in 1 [44] \\
\hline & Nicotine & 3 RCTs [78-80] \\
\hline & Replacement & Efficacy on SUD in $2,[78,79]$ efficacy NA \\
\hline & Therapy & $\begin{array}{l}\text { in } 1[80] \\
\text { No efficacy on SCZ in 2,[79,80] efficacy NA } \\
\text { in } 1[78]\end{array}$ \\
\hline & Varenicline & 4 RCTs $[81-83,85]$ \\
\hline & & $\begin{array}{l}\text { Efficacy on SUD in } 2,[82,85] \text { no efficacy in } 2 \\
{[81,83]}\end{array}$ \\
\hline & & $\begin{array}{l}\text { Efficacy on SCZ in } 1,[83] \text { no efficacy in } 3 \\
{[81,82,85]}\end{array}$ \\
\hline & Bupropion & 8 RCTs [83,89-96] \\
\hline & & $\begin{array}{l}\text { Efficacy on SUD in } 4,[89,90,92,93,95] \text { no } \\
\text { efficacy in } 4[83,91,94,96]\end{array}$ \\
\hline & & $\begin{array}{l}\text { Efficacy on SCZ in } 2,[89,92,93] \text { no efficacy in } 6 \\
{[83,90,91,94-96]}\end{array}$ \\
\hline & Galantamine & 1 RCT [97] \\
\hline & & No efficacy on SUD [97] \\
\hline & & Efficacy on SCZ NA [97] \\
\hline & Mecamylamine & $1 \mathrm{RCT}[98]$ \\
\hline & & No efficacy on SUD [98] \\
\hline & & No efficacy on SCZ [98] \\
\hline \multirow[t]{8}{*}{ Cocaine } & Desipramine & 1 RCT [68] \\
\hline & & Efficacy on SUD [68] \\
\hline & & Efficacy on SCZ [68] \\
\hline & Haloperidol & 2 RCTs $[34,35]$ \\
\hline & & Efficacy on SUD in $1,[34]$ no efficacy in 1 [35] \\
\hline & & Efficacy on SCZ in $2[34,35]$ \\
\hline & Olanzapine & 2 RCTs $[34,35]$ \\
\hline & & $\begin{array}{l}\text { Efficacy on SUD in 1,[35] no efficacy in } 1[34] \\
\text { Efficacy on SCZ in } 2[34,35]\end{array}$ \\
\hline \multirow[t]{6}{*}{ Cannabis } & Clozapine & 2 RCTs $[41,46]$ \\
\hline & & Efficacy on SUD in $2[41,46]$ \\
\hline & & Efficacy on SCZ in $2[41,46]$ \\
\hline & & $1 \mathrm{RCT}[41]$ \\
\hline & Ziprasidone & Efficacy on SUD [41] \\
\hline & & Efficacy on SCZ [41] \\
\hline
\end{tabular}

Notes: RCT: randomised controlled trial; SUD: substance use disorder; SCZ: schizophrenia; PLA: placebo; NA: not assessed.

This table refers to those comorbid schizophrenic patients who had all one and the same SUD when included in the respective studies.

\section{Expert opinion}

\subsection{What can we really learn from RCTs?}

The results of RCTs conducted in schizophrenic patients with comorbid SUD are difficult to interpret. This is particularly true for those involving antipsychotic drugs due to the lack of placebo arm, the small sample sizes, the heterogeneity in inclusion criteria and for some, the short duration of the trials. Furthermore, the doses of the antipsychotics compared are not 
always equivalent. For example, two studies [34,35] compared $10 \mathrm{mg}$ haloperidol with $10 \mathrm{mg}$ olanzapine, whereas the equivalent dose for olanzapine should be 20 mg.[103] Finally, RCTs in this area are scarce. Of the five studies that compared FGAs with SGAs, four found no difference on schizophrenia psychopathology,[3337] whereas one favoured the SGA [39]; regarding the efficacy on SUD, one favoured the FGA,[34] two the $S G A,[35,36]$ while there was no report in the other two.[33,37] In the three studies in which side effects were assessed,[34,36,37] SGAs did better as regards EPS in two of them.[34,36] With respect to dropout rates, which were reported in four studies, no significant differences were found in two of them, $[34,35]$ whereas the other two[33,36] reported fewer dropouts in the SGA arm. Despite the above-mentioned limitations, these studies indicate some trend in favour of SGAs. This is consistent with the findings of some pilot trials [104] which suggest that the benefit observed with SGAs might be explained by a reduction in side effects, psychopathology or craving. Concerning the four comparisons between SGAs, three [38-40] found no difference for schizophrenic symptoms, whereas one favoured clozapine, but in the same study ziprasidone was superior to clozapine as regards adherence to treatment.[41] In these four studies, no difference between treatments was found concerning the efficacy on SUD. In the three studies that reported the side effects,[38,40,41] one [40] found weight gain with olanzapine and risperidone, with a greater but non-significant increase in olanzapine-treated patients. There was no difference between olanzapine and risperidone on EPS in the third study.[38] Studies conducted according to another design are far less informative: studies dealing with clozapine in refractory schizophrenic patients with nicotine use [42-44] just confirm a greater efficacy on schizophrenic symptoms at higher doses, while the effect on tobacco use seems to be less clear. The study by Brunette et al. [46] found some effect of clozapine on cannabis use but did not report on the nature of the antipsychotic treatment included in the comparison arm. Moreover, and quite surprisingly, the study found no superiority of clozapine on schizophrenic symptoms. In the study by Brown et al.,[45] patients treated with quetiapine showed improvement in psychosis and cocaine/amphetamine craving compared to patients with discontinued antipsychotic treatment; however, since quetiapine was instituted in case of psychotic relapse, it is likely that improvements are just reflecting the efficacy of the drug on reducing psychosis worsening. The results of the study by Leatherman et al.,[47] however interesting, may be tricky to interpret, particularly owing to the lack of information on the antipsychotics used in the control group.

Since, in the eight studies based on direct comparisons between two drugs, three involved oral risperidone and six oral olanzapine, we have compared the mean dropout rates for these drugs. We found a mean of $38 \%$ for olanzapine vs. $23.2 \%$ for risperidone, which may suggest a trend in favour of risperidone. The corresponding dropout rates for FGAs vs. SGAs were $34.6 \%$ vs. $29.7 \%$, respectively. Interestingly, when we compared the dropout rates for oral risperidone with those for LAI risperidone reported in the study by Rubio et al.,[36] they were $23.2 \%$ vs. $5.2 \%$, respectively (in the same study, the dropout rate was $10.3 \%$ for LAI zuclopenthixol).

It is worth noting in this context that the study by Rubio et al. [36] found LAI risperidone to be superior to LAl zuclopenthixol with respect both to improvement of psychotic symptoms and the efficacy on SUD. Patients treated with LAI risperidone also showed fewer EPS and better adherence to a SUD management programme.

If two RCTs confirmed the efficacy of both FGAs and SGAs on cannabis-induced psychotic disorders, $[65,66]$ however no efficacy of antipsychotics over placebo was found for cocaine use or craving in patients with no psychotic disorder, despite a trend in favour of aripiprazole.[50] Interestingly, two RCTs $[61,62]$ suggested an efficacy of this antipsychotic for alcohol dependence. However, no RCT has been conducted so far with this drug in schizophrenic patients with comorbid SUD. Less clear results emerged from RCTs conducted with antipsychotics in patients with primary alcohol dependence.

Otherwise, RCTs seem to confirm that other psychotropic drugs, like TCAs or some other medications, used to treat specific primary SUDs may be efficiently prescribed for schizophrenic patients with SUD. Despite the lack of RCTs, some experts [26] stated that there was no reason to believe that acamprosate for alcohol dependence and both methadone and buprenorphine for opioid dependence should not be prescribed to schizophrenic patients with SUD. This could also concern other medications of the same type. For example, the European Psychiatric Association guidance on tobacco dependence and strategies for smoking cessation in people with mental disorder [105] recommends nicotine replacement therapy and varenicline for the treatment of tobacco dependency in schizophrenia. Nicotine replacement therapy is also recommended for these patients by the World Federation of Societies of Biological Psychiatry guidelines.[106] 


\subsection{The adherence issue}

If up to $60 \%$ of people with schizophrenia may show poor adherence to treatment,[107-109] this seems to be particularly true for those with comorbid SUD.[110] It was found in an outcome study of schizophrenic patients that those with current SUD were eight times more likely to report medication non-adherence in comparison with people with no SUD.[111] Furthermore, SUD was shown to be a significant predictor of medication non-adherence in a large database.[112] Schizophrenic patients with comorbid SUD were found to discontinue medication quicker than the non-comorbid patients, those with cannabis use showing the most rapid discontinuation.[113] Some studies have suggested that schizophrenic patients discontinue antipsychotics during phases of active substance use due to concerns about medication-drug interactions.[23] Furthermore, poor medication adherence was found to be higher in patients lacking social support or in the early phases of their disorders, which is when they are also among the most liable to SUD.[114] Accounting for patient preferences and implementing adherence management programmes may contribute to improving adherence in these patients; however, using an LAl appears to be particularly beneficial to ensure treatment delivery.[115] Moreover, as people with SUD may be particularly sensitive to the side effects of antipsychotic drugs, LAls could contribute to decreasing this risk owing to lower variations in plasma concentrations of the drug.[116]

\subsection{The medical comorbidity issue}

In schizophrenic patients, the presence of comorbid SUD has been shown to be deleterious to the physical health condition, leading to approximately $30 \%$ more somatic diagnoses per case than in its absence.[117] Chronic high-dose alcohol consumption may affect several organ systems, in particular the digestive system, the cardiovascular system and the central and peripheral nervous systems.[70] $A$ causal relation has been shown between smoking and many medical conditions, including cancer and cardiovascular and respiratory diseases.[70] Several general medical conditions have also been associated with cocaine use, depending on the drug's route of administration.[70] Chronic cannabis smoking has been associated with visceral adiposity and adipose tissue insulin resistance.[118] In addition to the presence of life-threatening infections, opioid dependence has also been associated with several other general medical complications.[70] A study reported that the odds ratios for having diabetes, heart disease, asthma, skin infections, cancer, respiratory and gastrointestinal disorders were higher in patients with co-occurring schizophrenia and SUD compared to patients with schizophrenia and no SUD.[119] So it seems therefore particularly important for such people, to avoid medications liable to increase these risks and some SGAs, especially those with metabolic effects, may be concerned.

\subsection{The impact on brain structures}

There is increasing evidence that drugs involved in SUD may lead to alteration in cortical and subcortical brain structures; this has been particularly well documented in the case of marijuana exposure.[120] Progressive brain changes in schizophrenia have been related to antipsychotic exposure.[121-123] Nevertheless, the debate is still open as to whether differential changes may be associated with the use of SGAs compared to FGAs.[123-125] This is based on magnetic resonance imaging (MRI) studies conducted in humans. On the other hand, plenty of animal and post-mortem human studies have now documented the destructive effects of FGAs on brain tissue, which is particularly true in the case of haloperidol.[126-132] This work has shown that haloperidol may be neurotoxic, and there is a debate on whether it should be banned.[133] Interestingly, it was found that, in the early phases of the disease, LAl risperidone might formally impact brain alterations, compared with oral risperidone, which was interpreted as the consequence of better adherence.[134,135] Nevertheless, in clinical practice there are still some patients who will only respond to butyrophenones.

\subsection{Pharmacodynamic and pharmacokinetic interactions}

There may be several potential pharmacodynamic and pharmacokinetic interactions between the medications and the substances involved in SUD, as well as among the medications themselves and the SUD substances themselves.[23]

The adrenergic properties of cocaine and amphetamines may potentiate the cardiovascular effects of antipsychotics, whereas the anticholinergic effects of the latter could be enhanced by cannabis.[136] Likewise, alcohol and opioids are likely to potentiate 
the sedative effects of antipsychotics sharing antihistaminergic properties.[136] It was also shown that cocaine-induced hyperthermia could be enhanced by antipsychotic medication, probably through dopaminergic mechanisms.[137] A triggering of hypertensive crises while taking antidepressants was reported in patients with concomitant use of drugs with adrenergic stimulation.[23] Concurrent use of ethanol and psychostimulants may produce greater increases in blood pressure than when either drug is taken alone.[138] Cocaine and nicotine may exert synergetic effects on myocardial oxygen supply, arterial pressure and cardiac contractility.

As far as pharmacokinetic interactions are concerned, plasma levels of antipsychotics may be decreased by concomitant alcohol use [139] or administration of disulfiram,[28] whereas smoking cessation is likely to increase these levels.[70] Conversely, clozapine was reported to increase plasma cocaine levels in a dose-dependent manner. [140] Plasma concentrations of methadone can be raised by drugs like TCAs and reduced by carbamazepine.[70] Concurrent use of alcohol and cocaine could increase the risk of cardiovascular toxicity possibly resulting from the formation of an active ethanol-induced metabolite, cocaethylene, which is more reinforcing than cocaine and potentially more toxic. [138] Alcohol could also slow down methamphetamine metabolism and thus increase the concentration of 3,4-methylenedioxy-methamphetamine by 9-15\%.[138]

These pharmacodynamic as well as pharmacokinetic potential interactions emphasise the need for regular monitoring of psychotropic drug side effects and, as far as possible, antipsychotic plasma concentrations in this population, especially in patients using more than one substance.

As a conclusion, if information from RCTs, for the treatment of schizophrenic patients with comorbid SUD is relatively limited, one has to take into account several parameters specific to this population. Among them, the most prominent are: poor adherence to treatment, the high rates of medical comorbidity, the potential neurotoxicity of FGAs like haloperidol and the high frequency of various pharmacodynamic and pharmacokinetic interactions.

\subsection{Recommendations and practice guideline}

\subsubsection{Improvement of psychopathology}

Antipsychotic drugs are the cornerstone of pharmacological treatment of schizophrenia with comorbid SUD, at least as regards the improvement of psychopathology.
The best evidence from RCTs concerning FGAs is for haloperidol. Siris [23] has recommended to preferentially use high-potency FGAs instead of low-potency FGAs for the treatment of acute substance-induced intoxication. As the former have a lower affinity for adrenergic, histaminergic or cholinergic receptors, they are less likely to cause adverse effects such as hypotension, tachycardia or sedation. This was confirmed by a recent Cochrane review.[141] High-potency FGAs are therefore less likely to potentiate the antiadrenergic, antihistaminergic or anticholinergic side effects that may result from many abused substances. However, haloperidol conveys a high risk of EPS,[142] may have a negative impact on brain structures[133] and has been suspected to contribute to compulsive drug-seeking and drug-taking behaviours in vulnerable schizophrenic patients.[22] Among SGAs, RCTs provide some evidence for a beneficial effect of olanzapine and clozapine. However, these drugs are more likely to cause metabolic effects compared to other SGAs and medium- and high-potency FGAs.[142] We do not therefore recommend them as first-line treatment for schizophrenic patients with SUD, as these patients are at a high risk of medical comorbidity. The risk is lower for quetiapine, but evidence from RCTs is weak. Ziprasidone was associated with an increase in corrected QT (QTC) interval but recent data indicated there was not a very high risk for clinically relevant QTc prolongation.[143] The study that compared ziprasidone to clozapine in schizophrenic patients with SUD,[41] used off-label doses of ziprasidone. Actually, in many countries, ziprasidone is approved at a dosage lower than $200 \mathrm{mg}$ (the medium dosage in this study).[144] For treatment-resistant schizophrenia with comorbid SUD, there are several hints that clozapine may be the best choice. However, this is based on case reports and open studies, but not on RCTs.[145] Nevertheless, based on existing RCTs, one may prefer olanzapine or haloperidol for the treatment of schizophrenic patients with cocaine use, and clozapine or ziprasidone for those who are using cannabis (Table 3 ). The efficacy of risperidone was shown in four [36,38-40] of the RCTs conducted in schizophrenic patients with comorbid SUD. Moreover, the only RCT that tested the efficacy of LAI in this indication demonstrated a superiority of LAI risperidone over LAI zuclopenthixol.[36] The risk of EPS and metabolic effects is considered to be intermediate for risperidone, and the risk for QTC prolongation is low. [142] For these reasons, risperidone should be considered as a first-line treatment. One can object that the basis for this recommendation remains weak, as there is no study proving a superiority of risperidone compared with any other SGA for these patients. 
However, our recommendation takes into account the availability of an LAI preparation as well as the results of the aforementioned comparative trial vs. LAI zuclopenthixol, even though dosage problems may be raised in this trial. This recommendation is also based on the LAI risperidone trial in the early phases of the disease showing its impact on brain alterations.[134,135] Moreover, we previously saw how poor treatment adherence was in schizophrenic patients with SUD; LAls are generally useful for poorly adherent patients and recent surveys have demonstrated that they may be better accepted by the patients than estimated by health care providers. [146] There are no RCTs addressing the efficacy of other SGAs on schizophrenic symptoms in comorbid patients with SUD. This may be particularly unfortunate in the case of aripiprazole, because it has one of the lowest potentials for EPS, metabolic effects, as well as QTc prolongation. Furthermore, a LAI depot preparation of aripiprazole is now available. Finally, anticraving agents like bupropion were also found to have some impact on negative and/or depressive symptoms in RCTs (Table 2).

What is suggested by RCTs is that antipsychotic drugs are effective in the treatment of psychotic exacerbations generated by substances of abuse in non-schizophrenic individuals as well as the idiopathic psychosis of schizophrenia; moreover, they may reduce psychotic relapses in the long term. There are no studies on dosage to guide clinicians for the treatment of acute psychotic exacerbation in schizophrenia that may be generated by substances of abuse; however, most experts do not usually recommend using doses higher than those in non-comorbid patients.[23,28] The substance that may have triggered the psychotic exacerbation is likely to pass out of the patient's system quickly if the patient is kept away from the source of the substance; moreover, high antipsychotic doses may sometimes stimulate him to use more substances.[23]

This underlines the need to discuss with the patients, as far as possible, the subjective states that are contributing to their addictive behaviour.[23] Actually, this may be the basis for mindfulness-based interventions, [147] and there is evidence that such interventions may prevent SUD relapse.[148]

In this regard, despite their potential of abuse in these patients, benzodiazepines might also be used by those who are attempting to self-medicate a state of anxiety.[23] In this case, they may reduce the necessary dose of antipsychotic required to treat an exacerbation of psychosis.[23]
Likewise, antidepressants may be recommended if addictive behaviour is driven by depressive states, or in the case of comorbid panic attacks.[23]

\subsubsection{Reduction of substance use}

RCTs conducted in schizophrenic patients with comorbid SUD have shown that antipsychotics may reduce craving and substance use. However, it is difficult to draw any firm conclusion on their efficacy, given the lack of placebo-controlled studies. In primary substance users, there are some hints that olanzapine [57] or quetiapine [59] may reduce alcohol intake, but this is limited to subgroups of patients. For comorbid patients, it is likely that the efficacy of antipsychotics on SUD depends on their efficacy on schizophrenic symptoms. The case of aripiprazole deserves special attention: this drug showed some efficacy on craving and substance intake compared to a placebo, both in patients with primary cocaine or psychostimulant dependence [50] as well as in patients with alcohol dependence.[61,62] This efficacy adds credit to the hypothesis of a shared vulnerability among schizophrenic and substance use patients, and is supported by the mode of action of D2/D3 partial agonists.[149,150] However, no RCTs have been conducted so far to confirm this efficacy in schizophrenic patients with comorbid SUD. TCAs such as imipramine and desipramine have also demonstrated some efficacy against cocaine use in these patients [67-69] and can be used as adjunctive treatment to antipsychotics. As far as benzodiazepines are concerned, they may be useful to treat many forms of acute substance-induced toxic states [23] or to control withdrawal symptoms.[23,28,70] Anticonvulsants may also be useful for the latter.[70]

Regarding the use of anticraving agents, the best evidence may be for naltrexone and disulfiram in case of alcohol use, and bupropion for tobacco cessation. However, it is important to remember that disulfiram can itself induce psychoses, probably due to its blockade of dopamine-beta hydroxylase.[151] As far as bupropion is concerned, one should also be aware that it could increase dopamine, worsen schizophrenic symptoms and lower the epileptic seizure threshold. [69] As previously mentioned, it is likely that other medications used to treat primary SUD could be indicated for schizophrenic patients with SUD, despite the lack of evidence in this population.

Since no drug is currently approved for the treatment of schizophrenia with comorbid SUD, it may be important for clinicians to easily access the results of 
clinical trials conducted in comorbid patients. This could help them make the best decisions. For example, varenicline is approved by the Food and Drug Administration (FDA) for the treatment of nicotine addiction, but seems to be less efficient in schizophrenia with nicotine addiction. In this case, a clinician prescribing varenicline to a schizophrenic patient with nicotine addiction, on the basis of drug labelling, might not be making the most appropriate decision.[152]

To summarise, for the treatment of schizophrenic symptoms, we favour the use of LAls in order to ensure better adherence. Among them, we recommend as first-line LAI risperidone, based on the results of RCTs, the frequency of medical comorbid conditions, the potential neurotoxicity of some FGAs and the warnings from the supersensivity hypothesis. LAI aripiprazole may share the same advantages; moreover, it could be also useful to treat comorbid SUDs such as cocaine and stimulant use as well as alcohol dependence, but data from RCTs are still lacking. For the reduction of substance use, the best evidence from RCTs is for naltrexone and disulfiram in case of alcohol use, and bupropion for tobacco cessation. Other psychotropic drugs and anticraving agents may also be useful in some situations or for the treatment of specific SUDs.

In any case, the assessment of schizophrenic patients with SUD should include lifetime symptoms of substance use, amounts, patterns and circumstances of use, perceived effects of substances, motivation, as well as drug screening.[28] Initial and regular physical health checks, monitoring of side effects and plasma levels of medications, with special attention to treatment adherence and potential pharmacological interactions, are particularly recommended in this population.

In addition to pharmacological treatment, it is essential to offer these patients psychosocial interventions targeting both schizophrenia and SUD management. This is usually referred to as integrated care' and includes flexible joint interventions, adapted to the characteristics and needs of each individual, by health care professionals from the fields of mental health and addiction

\section{Acknowledgements}

The authors would like to than Katherine Depax, Aix-Marseille University, and Justine Buand, Aix-Marseille University, for their assistance in the English language editing of this manuscript.

\section{Declaration of interest}

JM Azorin has received research support from, acted as a consultant for or been on the speaker's bureau for BristolMeyers Squibb, Janssen Pharmaceuticals, Eli Lilly, Otsuka, Takeda, Novartis, Pfizer, AstraZeneca, Servier and SanofiAventis. N Simon has received consulting fees from Lundbeck, Reckitt Benckiser Pharma, Merck/Serono and Ethypharm. M Adida has received research grants from Eli Lilly and Servier. $\mathrm{R}$ Belzeaux has received honoraria for conferences from AstraZeneca and Janssen. The authors have no other relevant affiliations or financial involvement with any organisation or entity with a financial interest in or financial conflict with the subject matter or materials discussed in the manuscript apart from those disclosed.

\section{References}

Papers of special note have been highlighted as either of interest $(\bullet)$ or of considerable interest $(\bullet)$ to readers

1. Frischer $M$, Collins J, Millson $D$, et al. Prevalence of comorbid psychiatric illness and substance misuse in primary care in England and Wales. J Epidemiol Community Health. 2004;58:1036-1041.

2. Moore E, Mancuso SG, Slade T, et al. The impact of alcohol and illicit drugs on people with psychosis: the second Australian National Survey of Psychosis. Aust N Z Psychiatry. 2012;46:864-878.

3. Kavanagh DJ, McGrath J, Saunders JB, et al. Substance misuse in patients with schizophrenia: epidemiology and management. Drugs. 2002;62:743-755.

4. Gupta S, Hendricks S, Kenkel AM, et al. Relapse in schizophrenia: is there a relationship to substance abuse? Schizophr Res. 1996;20:-153-156.

5. Green Al, Salomon MS, Brenner MJ, et al. Treatment of schizophrenia and comorbid substance use disorder. Curr Drug Targets CNS Neurol Disord. 2002;1:129-139.

6. Regier DA, Farmer ME, Rae DS, et al. Comorbidity of mental disorders with alcohol and other drug abuse. JAMA. 1990;264:2511-2518.

7. George TP, Vessichio JC, Termine A. Nicotine and tobacco use in schizophrenia. In: Meyer JM, Nasrallah HA, editors. Medical illness and schizophrenia. Arlington: American Psychiatric Publishing. Inc; 2003. p. 81-98.

8. Chambers RA, Krystal JH, Self DW. A neurobiological basis for substance abuse comorbidity in schizophrenia. Biol Psychiatry. 2001;50:71-83.

9. Littrel KH, Petty RG, Hilligoss NM, et al. Olanzapine treatment for patients with schizophrenia and substance abuse. J Subst Abuse Treat. 2001;21:217-221.

10. Soyka M, Albus M, Kathmann N, et al. Prevalence of alcohol and drug abuse in schizophrenic inpatients. Eur Arch Psychiatry Clin Neurosci. 1993;242:362-372.

11. Cohen LJ, Test MA, Brown RL. Suicide and schizophrenia: data from a prospective community treatment study. Am J Psychiatry. 1990;147:602-607.

12. Haywood TW, Kravitz HM, Grossman LS, et al. Predicting the "revolving door" phenomenon among patients with schizophrenic, schizoaffective, and affective disorders. Am J Psychiatry. 1995;152:856-861.

13. Kovasznay B, Fleischer J, Tanenberg-Karant $M$, et al. Substance use disorder and the early course of illness in 
schizophrenia and affective psychosis. Schizophr Bull. 1997;23:195-201.

14. Linszen DH, Dingemans PM, Lenior ME. Cannabis abuse and the course of recent-onset schizophrenic disorders. Arch Gen Psychiatry. 1994;51:273-279.

15. Rasanen P, Tiihonen J, Isohanni $M$, et al. Schizophrenia, alcohol abuse, and violent behavior: a 23-year followup study of an unselected birth cohort. Schizophr Bull. 1998;24:437-441.

16. Seibyl JP, Satel SL, Anthony D, et al. Effects of cocaine on hospital course in schizophrenia. J Nerv Ment Dis. 1993;181:31-37.

17. Swofford CD, Kasckow JW, Scheller-Gilkey G, et al. Substance use: a powerful predictor of relapse in schizophrenia. Schizophr Res. 1996;20:145-151.

18. Swartz MS, Wagner HR, Swanson JW, et al. Substance use in persons with schizophrenia: baseline prevalence and correlates from the NIMH CATIE study. J Nerv Ment Dis. 2006;194:164-172.

19. Khantzian EJ. The self-medication hypothesis of addictive disorders: focus on heroin and cocaine dependence. Am J Psychiatry. 1985;142:1259-1264.

-. A presentation of the most classic hypothesis about the comorbidity of schizophrenia and SUD.

20. Blanchard JJ, Squires D, Henry T, et al. Examining an affect regulation model of substance abuse in schizophrenia: the role of traits and coping. J Nerv Ment Dis. 1999;187:72-79.

21. Green Al, Zimmets SV, Strous RD, et al. Clozapine for comorbid substance use disorder and schizophrenia: do patients have a reward-deficiency syndrome that can be ameliorated by clozapine?. Harv Rev Psychiatry. 1999;6:287-296.

22. Samaha AN. Can antipsychotic treatment contribute to drug addiction in schizophrenia?. Progress Neur Psychopharmacol Biol Psychiatry. 2014;52:9-16.

- An excellent review on the reasons why drug abuse and addiction are so prevalent in schizophrenia and which makes the case for a contribution of FGAs to drug addiction.

23. Siris SG. Pharmacological treatment of substance-abusing schizophrenic patients. Schizophr Bull. 1990;16:111122.

- An excellent review on the pharmacological treatment of schizophrenic patients with SUD, which stays very close to the preoccupations of clinicians.

24. Wilkins JN. Pharmacotherapy of schizophrenia patients with comorbid substance abuse. Schizophr Bull. 1997;23:215-228.

25. San L, Arranz B, Martinez-Raga J. Antipsychotic drug treatment of schizophrenic patients with substance abuse disorders. Eur Addict Res. 2007;13:230-243.

- A comprehensive review in the field which details for each antipsychotic the available evidence.

26. Smelson DA, Dixon L, Craig T, et al. Pharmacological treatment of schizophrenia and co-occuring substance use disorders. CNS Drugs. 2008;22:903-916.

-. An outstanding review with a clear presentation of the different studies comparing FGAs vs SGAs as well as SGAs between them, and those about US-FDAapproved medications specifically for the treatment of SUD.
27. Wobrock T, Soyka M. Pharmacotherapy of schizophrenia with comorbid substance use disorder. Reviewing the clinical evidence and recommendations. Progr Neuropharmacol Biol Psychiatry. 2008;32:1375-1385.

-. An excellent review on psychotropic drugs and anticraving agents for the treatment of schizophrenia comorbid with SUD, accompanied by treatment recommendations.

28. Wobrock T, Soyka M. Pharmacotherapy of patients with schizophrenia and substance abuse. Expert Opin Pharmacother. 2009;10:353-367.

- An excellent review of open studies and RCTs conducted in schizophrenic patients with SUD which provides expert opinion on this topic.

29. Zhornitsky S, Rizkallah E, Pampoulova T, et al. Antipsychotic agents for the treatment of substance use disorders in patients with comorbid psychosis. J Clin Psychopharmacol. 2010;30:417-424.

-. An informative review on clinical studies of antipsychotics for substance users with and without comorbid psychosis.

30. Sepede G, Lorusso M, Spano MC, et al. Substance use in schizophrenia: efficacy of atypical antipsychotics. J Schizophr Res. 2014;1:1-12.

-. An evidence-based review focusing on the clinical studies of antipsychotics for the treatment of schizophrenic patients with SUD.

31. Kelly TM, Daley DC, Douaihy AB. Treatment of substance abusing patients with comorbid psychiatric disorders. Addict Behav. 2012;37:11-24.

-. An interesting review on interventions for psychiatric patients with SUD not focused on schizophrenia, but also dealing with depression, bipolar disorders, and anxiety.

32. Moher D, Liberati A, Tetzlaff J, et al. Preferred reporting items for systematic reviews and meta-analyses: the PRISMA statement. BMJ. 2009;339(b2535).

33. Green Al, Tohen MF, Hamer RM, et al. First episode schizophrenia-related psychosis and substance use disorders: acute response to olanzapine and haloperidol. Schizophr Res. 2004;66:125-135.

34. Sayers SL, Campbell EC, Kondrich J, et al. Cocaine abuse in schizophrenic patients treated with olanzapine versus haloperidol. J Nerv Ment Dis. 2005;193:379-386.

35. Smelson DA, Ziedonis D, Williams J, et al. The efficacy of olanzapine for decreasing cue-elicited craving in individuals with schizophrenia and cocaine dependence: a preliminary report. J Clin Psychopharmacol. 2006;26:9-12.

36. Rubio G, Martínez I, Ponce G, et al. Long-acting injectable risperidone compared with zuclopenthixol in the treatment of schizophrenia with substance abuse comorbidity. Can J Psychiatry. 2006;51:531-539.

-. The first RCT involving LAI antipsychotics in the treatment of schizophrenic patients with SUD.

37. Swartz MS, Wagner HR, Sawnson JW, et al. The effectiveness of antipsychotic medications in patients who use or avoid illicit substances: results from the CATIE study. Schizophr Res. 2008;100:39-52.

38. Akerele E, Levin FR. Comparison of olanzapine to risperidone in substance abusing individuals with schizophrenia. Am J Addic. 2007;16:260-268. 
39. Van Nimwegen LJ, De Haan L, Van Beveren NJ, et al. Effect of olanzapine and risperidone on subjective wellbeing and craving for cannabis in patients with schizophrenia or related disorders: a double blind randomized controlled trial. Can J Psychiatry. 2008;53:400-405.

40. Sevy S, Robinson DG, Sunday S, et al. Olanzapine vs. risperidone in patients with first-episode schizophrenia and a lifetime history of cannabis use disorders: 16-week clinical and substance use outcomes. Psychiatry Res. 2011;188:310-314.

41. Schnell T, Koethe D, Krasnianski A, et al. Ziprasidone versus clozapine in the treatment of dually diagnosed (DD) patients with schizophrenia and cannabis use disorders: a randomized study. Am Addict. 2014;23:308-312.

42. McEvoy JP, Freudenreich O, McGee M, et al. Clozapine decreases smoking in patients with chronic schizophrenia. Biol Psychiatry. 1995;37:550-552.

43. McEvoy JP, Freudenreich O, Wilson WH. Smoking and therapeutic response to clozapine in patients with schizophrenia. Biol Psychiatry. 1999;46:125-129.

44. De Leon J, Diaz FJ, Josiassen RC, et al. Does clozapine decrease smoking?. Prog Neuropsychopharmacol Biol Psychiatry. 2005;29:757-762.

45. Brown ES, Nejtek VA, Perantec DC, et al. Cocaine and amphetamine use in patients with psychiatric illness. A randomized trial of typical antipsychotic continuation or discontinuation. J Clin Psychopharmacol. 2003;23:284-288.

46. Brunette MF, Dawson R, O'Keefe CD, et al. A randomized trial of clozapine versus other antipsychotic for cannabis use disorder in patients with schizophrenia. J Dual Diagnosis. 2011;7:50-63.

47. Leatherman SM, Liang MH, Krystal JH, et al. Differences in treatment effect among clinical subgroups in a randomized clinical trial of long-acting injectable risperidone and oral antipsychotics in unstable chronic schizophrenia. J Nerv Ment Dis. 2014;202:13-17.

48. Rosenheck RA, Krystal JH, Lew R, et al. Long-acting risperidone and oral antipsychotics in unstable schizophrenia. N Engl J Med. 2011;364:842-851.

49. Gawin FH, Khalsa-Denison ME, Jatlow P. Flupenthixol and desipramine treatment of crack users: double blind results. Eur Neuropsychopharmacol. 1996;6:120-121.

50. Kishi T, Matsuda $\mathrm{Y}$, Iwata $\mathrm{N}$, et al. Antipsychotics for cocaine or psychostimulant dependence: systematic review and meta-analysis of randomized, placebo-controlled trials. J Clin Psychiatry. 2013;74:e1169-e1180.

-. An evidence-based demonstration of the overall lack of efficacy of antipsychotics for primary cocaine or psychostimulant dependence.

51. Shaw GK, Majumdar SK, Waller S, et al. Tiapride in the long term management of alcoholics of anxious or depressive temperament. Br J Psychiatry. 1987;150:164-168.

52. Shaw GK, Waller S, Sk M, et al Tiapride in the prevention of relapse in recently detoxified alcoholics. $\mathrm{Br} J$ Psychiatry. 1994;165:515-523.

53. Gual A, Monras M. Eficacia de tiapride en el mantenimiento de la abstinencia en alcohólicos desintoxicados. Resultados de un ensayo clínicos a doble ciego frente a placebo. Adicciones. 2002;14:321-326.

54. Bender S, Scherbaum N, Soyka M, et al. The efficacy of the dopamine D2/D3 antagonist tiapride in maintaining abstinence: a randomized double-blind placebo-controlled trial in 299 alcohol -dependent patients. Int J Neuropsychopharmacol. 2007;10:653-660.

55. Marra D, Warot D, Berlin I, et al. Amisulpride does not prevent relapse in primary alcohol dependence: results of a pilot randomized, placebo-controlled trial. Alcohol Clin Exp Res. 2002;26:1545-1552.

56. Wiesbeck GA, Weijers HG, Lesch OM, et al. Flupenthixol decanoate and relapse prevention in alcoholics: results from a placebo controlled study. Alcohol Alcohol. 2001;36:329-334.

57. Hutchison KE, Ray L, Sandman E, et at. The effect of olanzapine on craving and alcohol consumption. Neuropsychopharmacology. 2006;31:1310-1317.

58. Guardia J, Segura L, Gonzalvo B, et al. A double-blind, placebo controlled study of olanzapine in the treatment of alcohol-dependence disorder. Alcohol Clin Exp Res. 2004;28:736-745.

59. Kampman KM, Pettinati HM, Lynch KG, et al. A double blind, placebo-controlled pilot trial of quetiapine for the treatment of type A and type B alcoholism. J Clin Psychopharmacol. 2007;27:344-351.

60. Litten RZ, Fertig JE, Falk DE, et al. A double blind, placebo-controlled trial to assess the efficacy of quetiapine fumarate $\mathrm{XR}$ in very heavy-drinking alcohol-dependent patients. Alcohol Clin Exp Res. 2012;36:406-416.

61. Anton RF, Kranzler $\mathrm{H}$, Breder $\mathrm{C}$, et al. A randomized, multicenter, double-blind placebo-controlled study of the efficacy and safety of aripiprazole for the treatment of alcohol dependence. J Clin Psychopharmacol. 2008;28:5-12.

62. Martinotti G, Di Nicola M, Di Giannantonio M, et al. Aripiprazole in the treatment of patients with alcohol dependence: a double-blind, comparison trial vs. naltrexone. J Psychopharmacol. 2009;23:123-129.

63. Rounsaville BJ. DSM-V research agenda: substance abuse/ psychosis comorbidity. Schizophr Bull. 2007;33:947-952.

64. Jablensky A. Schizophrenia in DSM-5: assets and liabilities. Schizophr Res. 2013;150:36-37.

65. Berk M, Brook S, Trandafir Al. A comparison of olanzapine with haloperidol in cannabis-induced psychotic disorder: a double-blind randomized trial. Int Clin Psychopharmacol. 1999;14:177-180.

66. Berk M, Brook S, Nur F. Risperidone compared to haloperidol in cannabis-induced psychotic disorder: a double blind randomized controlled trial. Int J Psychiat Clin Pract. 2004;4:139-142.

67. Siris SG, Mason SE, Bermanzohn PC, et al. Adjunctive imipramine in substance-abusing dysphoric schizophrenia patients. Psychopharmacol Bull. 1993;29:127-133.

68. Wilkins JN, Gorelick DA, Levine D, et al. Double-blind trial of desipramine for treatment of cocaine-abusing schizophrenics. In: Harris LS editor. Problems of drug dependence, 1995. Proceedings of the $57^{\text {th }}$ Annual Scientific Meeting. Rockville, MD: NS. Department of Health and Human Services, National Institutes of Health, National Institute on Drug Abuse; 1996; 325.

69. Ziedonis D, Richardson T, Lee E, et al. Adjunctive desipramine in the treatment of cocaine abusing schizophrenics. Psychopharmacol Bull. 1992;28:309-314.

70. Kleber HD, Weiss RD, Anton RF, et al. Treatment of patients with substance use disorders, second edition. 
American Psychiatry Association. Am J Psychiatry. 2007;164(4Suppl.):5-123.

- An outstanding and extremely detailed review of evidence-based studies in the field, which provides clinicians with useful guidelines.

71. Brensilver $M$, Heinzerling KG, Shoptaw $S$. Pharmacotherapy of amphetamine-type stimulant dependence. Drug and Alcohol Review. 2013;32:449-469.

72. Fawcett J, Clark DC, Aagesen CA, et al. A double-blind, placebo-controlled trial of lithium carbonate therapy for alcoholism. Arch Gen Psychiatry. 1987;44:248-256.

73. Gawin FH, Kleber HD, Byck R, et al. Desipramine facilitation of initial cocaine abstinence. Arch Gen Psychiatry. 1989;46:117-181.

74. Petrakis IL, O'Malley S, Rounsaville B, et al. Naltrexone augmentation of neuroleptic treatment in alcohol abusing patients with schizophrenia. Psychopharmacology (Berl). 2004;172:291-297. Erratum in: Psychopharmacology (Berl). 2004;174:300.

75. Petrakis IL, Nich C, Ralevski E. Psychotic spectrum disorders and alcohol abuse: a review of pharmacotherapeutic strategies and a report on the effectiveness of naltrexone and disulfiram. Schizophr Bull. 2006;32:644-654.

76. Petrakis IL, Poling J, Levinson C, et al. Naltrexone and disulfiram in patients with alcohol dependence and comorbid psychiatric disorders. Biol Psychiatry. 2005;57:1128-1137.

77. Ralevski E, O'Brien E, Jane S, et al. Treatment with acamprosate in patients with schizophrenia spectrum disorders and comorbid alcohol dependence. J Dual Diagnosis. 2011;7:64-73.

78. Chou KR, Chen R, Lee JF, et al. The effectiveness of nicotine-patch therapy for smoking cessation in patients with schizophrenia. Int J Nurs Stud. 2004;41:321-330.

79. Chen HK, Lan TH, Wu BJ. A double-blind randomized clinical trial of different doses of transdermal nicotine patch for smoking reduction and cessation in long-term hospitalized schizophrenic patients. Eur Arch Psychiatry Clin Neurosci. 2013;263:75-82.

80. Allen $M H$, Debanné $M$, Lazignac $C$, et al. Effect of nicotine replacement therapy on agitation in smokers with schizophrenia: a double-blind, randomized, placebo-controlled study. Am J Psychiatry. 2011;168:395-399.

81. Weiner $E$, Buchholz A, Coffay $A$, et al. Varenicline for smoking cessation in people with schizophrenia: a double blind randomized pilot study. Schizophr Res. 2011;129:94-95.

82. Williams JM, Anthenelli RM, Morris CD, et al. A randomized, double-blind, placebo-controlled study evaluating the safety and efficacy of varenicline for smoking cessation in patients with schizophrenia or schizoaffective disorder. J Clin Psychiatry. 2012;73:654-660.

83. Fatemi SH, Yousefi MK, Kneeland RE, et al. Antismoking and potential antipsychotic effects of varenicline in subjects with schizophrenia or schizoaffective disorder: a double-blind placebo and bupropion-controlled study. Schizophr Res. 2013;146:376-378.

84. Meszaros ZS, Abdul-Malak Y, Dimmock JA, et al. Varenicline treatment of concurrent alcohol and nicotine dependence in schizophrenia: a randomized, placebocontrolled pilot trial. J Clin Psychopharmacol. 2013;33:243-247.
85. Evins AE, Cather C, Pratt SA, et al. Maintenance treatment with varenicline for smoking cessation in patients with schizophrenia and bipolar disorder: a randomized clinical trial. JAMA. 2014;311:145-154.

86. Kishi T, Iwata N. Varenicline for smoking cessation in people with schizophrenia: systematic review meta-analysis. Eur Arch Psychiatr. Clin Neurosci. 2015;265:259-268.

87. Hong LE, Thaker GK, McMahon RP, et al. Effects of moderate-dose treatment with varenicline on neurobiological and cognitive biomarkers in smokers and nonsmokers with schizophrenia or schizoaffective disorder. Arch Gen Psychiatry. 2011;68:1195-1206.

88. Shim JC, Jung DU, Jung SS, et al. Adjunctive varenicline treatment with antipsychotic medications for cognitive impairments in people with schizophrenia: a randomized double-blind placebo-controlled trial. Neuropsychopharmacology. 2012;37:660-668.

89. Evins $A E$, Mays $V K$, Rigotti $N A$, et al. A pilot trial of bupropion added to cognitive behavioral therapy for smoking cessation in schizophrenia. Nicotine Tob Res. 2001;3:397-403.

90. George TP, Vessicchio JC, Termine A, et al. A placebo controlled trial of bupropion for smoking cessation in schizophrenia. Biol Psychiatry. 2002;52:53-61.

91. Fatemi SH, Stary JM, Hatsukami DK, et al. A double-blind placebo-controlled cross over trial of bupropion in smoking reduction in schizophrenia. Schizophr Res. 2005;76:353-356.

92. Evins $A E$, Cather $C$, Deckersbach $T$, et al. A double-blind placebo-controlled trial of bupropion sustained-release for smoking cessation in schizophrenia. J Clin Psychopharmacol. 2005a;25:218-225.

93. Evins $A E$, Deckersbach $T$, Cather $C$, et al. Independent effects of tobacco abstinence and bupropion on cognitive function in schizophrenia. J Clin Psychiatry. 2005b;66:1184-1190.

94. Weiner E, Ball MP, Buchholz AS, et al. Bupropion sustained release added to group support for smoking cessation in schizophrenia: a new randomized trial and a meta-analysis. J Clin Psychiatry. 2012;73:95-102.

95. Evins AE, Cather C, Culhane MA, et al. A 12-week doubleblind, placebo-controlled study of bupropion sr added to high-dose dual nicotine replacement therapy for smoking cessation or reduction in schizophrenia. J Clin Psychopharmacol. 2007;27:380-386.

96. George TP, Vessicchio JC, Sacco KA, et al. A placebocontrolled trial of bupropion combined with nicotine patch for smoking cessation in schizophrenia. Biol Psychiatry. 2008;63:1092-1096.

97. Kelly DL, McMahon RP, Weiner E, et al. Lack of beneficial galantamine effect for smoking behavior: a double-blind randomized trial in people with schizophrenia. Schizophr Res. 2008;103:161-168.

98. Weinberger $A H$, Sacco KA, Creeden $C L$, et al. Effects of acute abstinence, reinstatement, and mecamylamine on biochemical and behavioral measures of cigarette smok ing in schizophrenia. Schizophr Res. 2007;91:217-225.

-. An up-to-date meta-analysis of $\mathbf{R C T}_{s}$ involving varenicline for smoking cessation in schizophrenia with SUD.

99. Weinberger AH, George TP, Perkins KA, et al. Effects of topiramate on smoking in patients with schizoaffective 
disorders, bipolar type. J Clin Psychopharmacol. 2008;28:247-248.

100. Sacco KA, Creeden C, Rentenaner EL, et al. Effects of atomoxetine on cognitive functions and cigarette smoking in schizophrenia. Schizoph Res. 2009;107:332-333.

101. Tsoi DT, Porwal M, Webster AC. Interventions for smoking cessation and reduction in individuals with schizophrenia. Cochrane Database Syst Rev. 2013;2:CD007253.

- A meta-analysis of RCTs involving both pharmacological and psychosocial interventions for smoking cessation in schizophrenia with SUD.

102. Volkow ND, Fowler JS, Wang GJ, et al. Dopamine in drug abuse and addiction: results from imaging studies and treatment implications. Mol Psychiatry. 2004;9:557-569.

- A brilliant and evidence-based argumentation for the role of dopamine in drug use and which is paving the way for newer therapeutic strategies.

103. Andreasen NC, Pressler $M$, Nopoulos $P$, et al. Antipsychotic dose equivalents and dose-years: a standardized method for comparing exposure to different drugs. Biol Psychiatry. 2010;67:255-262.

104. Tsuang J, Marder SR, Han A, et al. Olanzapine treatment for patients with schizophrenia and cocaine abuse. J Clin Psychiatry. 2002;63:1180-1181.

105. Rüther T, Bobes J, De Hert M, et al. EPA Guidance on tobacco dependence and strategies for smoking cessation in people with mental illness. Eur Psychiatry. 2014;29:65-82.

106. Hasan A, Falkai P, Wobrock T, et al. Guidelines of Biological Treatment of Schizophrenia. Part 3. Update 2015. Management of special circumstances. Depression, suicidality, substance use disorders and pregnancy and lactation. World J Biol Psychiatry. 2015;16:142-170.

- An up-to-date guideline in the field with a gradation of recommendations for both psychotropic and anticraving agents when administered to schizophrenic patients with SUD.

107. Gilmer TP, Dolder CR, Lacro JP, et al. Adherence to treatment with antipsychotic medication and health care costs among Medicaid beneficiaries with schizophrenia. Am J Psychiatry. 2004;161:692-699.

108. Becker MA, Young MS, Ochshorn E, et al. The relationship of antipsychotic medication class and adherence with treatment outcomes and costs for Florida Medicaid beneficiaries with schizophrenia. Adm Policy Ment Health. 2007;34:307-314.

109. Velligan DI, Wang M, Diamond $P$, et al. Relationships among subjective and objective measures of adherence to oral antipsychotic medications. Psychiatric Services. 2007;58:1187-1192.

110. Margolese HC, Malchy L, Negrete JC, et al. Drug and alcohol use among patients with schizophrenia and related psychoses: levels and consequences. Schizophr Res. 2004;67:157-166.

111. Owen RR, Fischer EP, Booth BM, et al. Medication noncompliance and substance abuse among patients with schizophrenia. Psychiatric Services. 1996;47:853-858.

112. Kreyenbuhl J, Slade EP, Medoff DR, et al. Time to discontinuation of first-and second-generation antipsychotic medications in the treatment of schizophrenia. Schizophr Res. 2011;131:127-132.
113. Smelson D, Tunis SL, Aw N, et al Substance use and antipsychotic treatment discontinuation in a 1 year randomized open label antipsychotic trial for schizophrenia. J Clin Psychopharmacol. 2006;26:666-667.

114. Agarval MR, Sharma VK, Kishore Kumar KV, et al. Noncompliance with treatment in patients suffering for schizophrenia: a study to evaluate possible contributing factors. Int J Soc Psychiatry. 1998;44:92-106.

115. Koola MM, Wehring HJ, Kelly DL. The potential role of long-acting injectable antipsychotics in people with schizophrenia and comorbid substance use. J Dual Diagn. 2012;8:50-61.

-. An excellent review which makes the case for the use of LAls in schizophrenic patients with SUD.

116. Stip $E$, Abdel-Baki A, Bloom D, et al. Long-acting injectable antipsychotics: an expert opinion from the Association des médecins psychiatres du Québec. Can J Psychiatry. 2011;56:367-375.

.- A rational guideline for the use of $L A$ antipsychotics.

117. Adrian M, Barry SJ. Physical and mental health problems associated with use of alcohol and drugs. Subst Use Misuse. 2003;38:1575-1614.

118. Muniyappa R, Sable S, Ouwerkerk R, et al. Metabolic effects of chronic cannabis smoking. Diabetes Care. 2013;36:2415-2422.

119. Dickey B, Azeni H. Persons with dual diagnoses of substance abuse and major mental illness: their excess costs of psychiatric care. Am J of Public Health. 1996;86:973-977.

120. Gilman JM, Kuster JK, Lee $S$, et al. Cannabis use is quantitatively associated with nucleus accumbens and amygdala abnormalities in young adult recreational users. J Neurosci. 2014;34:5538-5529.

121. Scherck H, Falkai P. Effects of antipsychotics on brain structure. Curr Opin Psychiatry. 2006;19:145-150.

122. Smieskova R, Fusar-Poli $P$, Allen $P$, et al. The effects of antipsychotics on the brain: what have we learnt from structural imaging of schizophrenia. A systematic review. Current Pharmaceutical Design. 2009;15:2535-2549.

123. Fusar-Poli P, Smieskova R, Kempton MJ, et al. Progressive brain changes in schizophrenia related to antipsychotic treatment ? A meta-analysis of longitudinal MRI studies. Neurosci Biobehav Rev. 2013;37:1680-1691.

124. Navari S, Dazzan P. Do antipsychotic drugs affect brain structure? A systematic and critical review of MRI findings. Psychol Med. 2009;39:1763-1777.

125. Moncrieff J, Leo J. A systematic review of the effects of antipsychotics drugs on brain volume. Psychol Med. 2010;40:1409-1422.

126. Gassó P, Mas S, Molina O, et al. Neurotoxic/neuroprotective activity of haloperidol, risperidone and paliperidone in neuroblastoma cells. Prog Neuropsychopharmacol Biol Psychiatry. 2012;36:71-77.

127. Gil-ad I, Shtaif B, Shiloh R, et al. Evaluation of the neurotoxic activity of typical and atypical neuroleptics: relevance to iatrogenic extrapyramidal symptoms. Cell Mol Neurobiol. 2001;21:705-716.

128. Jarskog LF, Gilmore JH, Glantz LA, et al. Caspase-3 activation in rat frontal cortex following treatment with typical and atypical antipsychotics. Neuropsychopharmacology. 2007;32:95-102. 
129. Qing H, Xu H, Wei Z, et al. The ability of atypical antipsychotic drugs vs haloperidol to protect PC12 cells against MPP +-induced apoptosis. Eur J Neurosc. 2003;17:1563-1570.

130. Skoblenick K, Castellano JM, Rogoza RM, et al. Translocation of AIF in the human and rat striatum following protracted haloperidol, but not clozapine treatment. Apoptosis. 2006;11:663-672.

131. Tan QR, Wang XZ, Wang CY, et al. Differential effects of classical and atypical antipsychotic drugs on rotenoneinduced neurotoxicity in PC12 cells. Eur Neuropsychopharmacol. 2007;17:768-773.

132. Ukai W, Ozawa H, Tateno M, et al. Neurotoxic potential of haloperidol in comparison with risperidone: implication of Akt-mediated signal changes by haloperidol. J Neural Transm. 2004;111:667-681.

133. Nasrallah H. Haloperidol clearly is neurotoxic. Should it be banned?. Curr Psychiatr. 2013;12:7-9.

134. Bartzokis G, Lu PH, Amar CP, et al. Long acting injection versus oral risperidone in first-episode schizophrenia: differential impact on white matter myelination trajectory. Schizophr Res. 2011;132:35-41.

135. Bartzokis G, Lu PH, Raven EP, et al. Impact on intracortical myelination trajectory of long acting injection versus oral risperidone in first-episode schizophrenia. Schizophr Res. 2012;140:122-128.

136. Johnson MD, Heriza TJ, Dennis CS. How to spot illicit drug abuse in your patients. Postgrad Med. 1999;106:199-218.

137. Kosten TR, Kleber HD. Rapid death during cocaine abuse: Variant of the neuroleptic malignant syndrome?. Am J Drug Alcohol Abuse. 1988;14:335-346.

138. Dean A. Illicit drugs and drug interactions. Pharmacist. 2006;25:684-689.

-. A brief but straightforward review of potential pharmacodynamic and pharmacokinetic interactions with substances of abuse and drug treatment.

139. Soni SD, Brownlee M. Alcohol abuse in chronic schizophrenics: implications for management in the community. Acta Psychiatr Scand. 1991;84:272-276.

140. Farren CK, Hameedi FA, Rosen MA, et al. Significant interactions between clozapine and cocaine in cocaine addicts. Drug and Alcohol Dependence. 2000;59:153-163.

141. Tardy M, Huhn M, Kissling W, et al. Haloperidol versus low-potency first-generation antipsychotic drugs for schizophrenia. Cochrane Database Syst Rev. Jul 2014;9 (7):CD 009268. DOI:10.1002/14651858. CD009268. pub2. Review.

142. Buchanan RW, Kreyenbuhl J, Kelly DL, et al. The 2009 Schizophrenia PORT Psychopharmacological Treatment Recommendations and summary statements. Schizoph Bull. 2010;36:71-93.

-. An outstanding review on the extrapyramidal, metabolic, and cardiovascular side effects of antipsychotics which provides comparative profiles of drugs for each of these effects.

143. Camm AJ, Karayal DN, Meltzer $\mathrm{H}$, et al. Ziprasidone and the corrected QT interval. A comprehensive summary of clinical data. CNS Drugs. 2012;26:351-365.

144. Greenberg WM, Citrome L. Ziprasidone for schizophrenia and bipolar disorder: a review of clinical trials. CNS Drug Rev. 2007;13:137-177.

145. Kelly DL, Gale EA, Conley RR, et al. Clozapine treatment in patients with prior substance abuse. Can J Psychiatry. 2003;48:111-114.

146. Wehring HJ, Thedford S, Koola $M$, et al. Patient and health care provider perspectives on long acting injectable antipsychotics in schizophrenia and the introduction of olanzapine long-acting injection. J Cent Nerv Syst Dis. 2011;3:107-123.

147. Varghese SP, Koola MM, Eiger R, et al. Opioid use remits, depression remains. Curr Psychiatr. 2014;13:45-50.

148. Bowen S, Chawla N, Collins SE, et al. Mindfulness-based prevention for substance use disorders: a pilot efficacy trial. Subst Abus. 2009;30:295-305.

149. Childress AR, O'Brien CP. Dopamine receptor partial agonists could address the duality of cocaine craving. Trends Pharmacol Sci. 2000;21:6-9.

150. Czoty PW, Nader MA. Effects of dopamine D2/D3 receptor ligands on food-cocaine choice in socially housed male cynomolgus monkeys. J Pharmacol Exp Ther. 2013;344:329-338.

151. Major LF, Lerner $P$, Ballenger JC, et al. Dopamine-betahydroxylase in the cerebrospinal fluid: relationship to disulfiram-induced psychosis. Biol Psychiatry. 1979;14:337-344.

152. Ventola CL. Off-label drug information. Regulation, distribution, evaluation, and related controversies. P\&T. 2009;34:428-440. 